\title{
Putting Hoover on the MaP: Was the 31st President A Progressive?
}

\author{
BARRY C. EDWARDS \\ Department of Political Science, University of Georgia, Athens, Georgia
}

\begin{abstract}
If any U.S. President is in need of a public image makeover, surely it is Herbert Hoover. Although not considered the nation's worst president, Hoover continues to serve as an object of derision in contemporary debates over economic policy. But is the textbook portrayal of Hoover as an unrelenting conservative historically accurate? A number of scholars assert that Hoover was a progressive president. Given Hoover's status in our political consciousness, the stakes in this debate are significant. Political science can inform this debate with rigorous ideological measurement. I complete a record of Hoover's legislative positions and use W-NOMINATE to estimate Hoover's ideal point relative to the 71 st and 72nd Congresses. I demonstrate a design to improve presidential ideal point estimation. The results fill a gap in presidential scholarship, show that Hoover was a conservative Republican, and suggest that efforts to portray Hoover as a progressive leader are misinformed.
\end{abstract}

If any U.S. president is in need of a public image makeover, surely it is Herbert Hoover. Although experts do not judge him to be the nation's worst president (Nice 1984; Nichols 2012), Hoover continues to serve as an object of derision in contemporary debates over economic stimulus and austerity measures. ${ }^{1}$ A substantial number of Hoover scholars, however, challenge the portrayal of Hoover as a laissezfaire conservative and maintain that Hoover was a progressive president (e.g., Best 1983; Burner 1974; Degler 1963; Jeansonne 2012; Wilson 1975). Have we misjudged Hoover? Unfortunately, political scientists have not been able to answer this question. Although we possess sophisticated tools for analyzing political behavior, Hoover has thus far eluded measurement.

In this article, I hope to shed light on this historical controversy by analyzing Hoover's legislative record with modern tools of political science. These tools allow us to map Hoover's ideological preferences relative to other actors and determine whether he stood with the right, left, or center of the Republican Party. We can also

Address correspondence to Barry C. Edwards, Department of Political Science, University of Georgia, 104 Baldwin Hall, Athens, GA 30602. E-mail: bce@uga.edu 
compare Hoover to progressive members of both parties. Based on the requests he made for legislative action, the bills he signed and vetoed, his nominees and a treaty he proposed, Hoover was significantly more conservative than his contemporaries in the House and Senate on most issues. This research fills a gap in our understanding of twentieth century presidents and demonstrates a robust method of estimating presidential ideal points. However progressive he may have been in spirit and personal affairs, Hoover did not act like a progressive while in office.

\section{"EXCAVATING" HERBERT HOOVER}

America's economic prospects were so bright in early 1929 that newly inaugurated President Herbert Hoover proclaimed that the end of poverty was near. In hindsight it is clear that Hoover could not have been more wrong. By the end of his administration, the country's gross national product was cut in half, the unemployment rate was 25\%, and Hoover was soundly defeated by Franklin Roosevelt in the 1932 presidential election. "Few Americans," Walch $(2004,1)$ aptly observed, "have known greater acclaim or more bitter criticism than Herbert Hoover."

This article will not attempt to diagnose the causes of the Great Depression. Whether policies enacted during the Hoover administration worsened the depression or those passed subsequently improved the economy is an ongoing controversy which I leave for economic historians. Similarly, I will not attempt a psychological analysis of Hoover's personal attitudes and beliefs. ${ }^{2}$ Instead, I focus on Hoover's policy-making decisions as president.

Conventional wisdom holds that Hoover was a laissez-faire conservative who stubbornly refused to compromise his ideological beliefs in response to the Great Depression (e.g., Leuchtenburg 2009). Indeed, Hoover has frequently served as a foil for Democratic candidates. According to Okun (1973, 275), "Nothing delights a Democratic congressman more than the opportunity to run against Herbert Hoover, and nothing offends the modern Republican more than to be tarred with the Hoover image." Similarly, Fausold $(1984,244)$ writes, "Democrats, every four years for more than half a century, seemed to be running against Herbert Hoover." In this perspective, Hoover is cast as poster boy for the far right. Liberals charge that conservative economic proposals constitute "Hooverism for the $21^{\text {st }}$ century" and risk precipitating economic collapse (Spitzer 2011; also see Evans-Pritchard 2011; King 2009; Matthews and Salas-Gage 2012).

But is this conventional account fair? According to Nash (2003, 10), Hoover is a "political orphan, unwelcome in liberal and conservative pantheons alike. ... Underlying this bipartisan aversion has been a continuing ambiguity in Hoover biography. Who was Hebert Hoover? Somehow, despite all the research and analysis, Hoover remains an elusive figure." ${ }^{3}$

A growing number of scholars challenge this familiar presentation of Hoover as an economic and social conservative. This high point of this movement is 
Herbert Hoover Reassessed, a volume edited by Senator Mark Hatfield (1981) and published by the U.S. Senate to commemorate the fiftieth anniversary of Hoover's inauguration. Reviewing a set of Hoover biographies penned by revisionist scholars, Romasco $(1984,139)$ observed, "the restoration of Hoover's reputation is a continuing and deepening historical commitment by Hoover scholars." He colorfully described this work as "the excavation of Hoover from the historical pit into which politically partisan detractors had cast him." Contemporary Hoover scholars challenge the "grotesque image" of Hoover that emerged in the 1932 election (Best 1983). ${ }^{4}$ Political historians have "refurbished" Hoover as part of the "simultaneous resurrection of the right and repudiation of liberal policies" (Quigley 2003; Ziegler 1976).

In revisionist interpretations, Hoover is more compassionate and forwardthinking than he appears in textbook accounts. According to these scholars, Hoover was progressive on both economic and social issues. Burner $(1974,54)$ maintained that Hoover was deeply committed to the ideal of equal opportunity and the eradication of poverty. Once in office, Hoover worked to "fire up the engines of Progressive reform." Degler $(1963,358)$ argued, "Hoover's principles were distinctly and publicly progressive." In a sweeping reappraisal of Hoover's life, Wilson $(1975,209)$ offered Hoover as a forgotten progressive: "There is a good deal of talk today about a 'new' Hoover. Disparate political groups ranging from the far right to the far left think they are rediscovering him, because his progressive philosophy contained ideas whose time has finally arrived." Wilson traces Hoover's progressivism to his Quaker upbringing, Stanford education, world travels, and forward-thinking administration of the Commerce Department (see also Best 1975). During the 1928 presidential campaign, Hoover made a concerted effort to appeal to female voters. After his landslide election, Hoover promptly convened a special session of Congress to culminate his "progressive dream for America" (Wilson 1975, 134). According to contemporary scholars, Hoover was particularly concerned about rural poverty, civil liberties (Burner 1979, Chapter 11), environmental conservation (Hatfield 1987), and opportunities for African Americans (Grothaus 1984). The image of Hoover as unremitting conservative, Wilson contended, resulted from his poor relationship with the media during his administration and the 1932 election as well as Hoover's outspoken opposition to Roosevelt's New Deal as an ex-president. More pointedly, Best $(1975, \mathrm{xv})$ pronounced the standard treatment of Hoover the product of "misinformation and distortion" and Lyons $(1948,1)$ lamented the "factually false and humanly unjust" image of Hoover in the public eye.

Both conventional and revisionist Hoover biographers select facts from Hoover's life to support often thinly veiled partisan agendas. Unfortunately, Hoover studies have been plagued with politicking, making it difficult to determine where the search for truth ends and spin doctoring begins. Nevertheless, the stakes in this debate between legacy managers (Ceasar 2011) are high. If Hoover was a progressive Republican with a liberal record, we need to reconsider our understanding of Hooverism and the origins of New Deal liberalism (Romasco 1974; Ziegler 1976). 
To the extent that the electoral realignment of 1932 was a rejection of Hoover, the revisionist interpretation of Hoover as progressive calls into question the political foundation of economic policies launched in Roosevelt's New Deal. Indeed, some observers have gone so far as to argue that the liberal course taken by the Hoover administration should be avoided to save the national economy from ruin (e.g., Continetti 2008; Foster 2011; Horwitz 2011).

A brief discussion of progressive politics may help us frame the debate over Hoover's legacy. It would be a mistake to judge Hoover's record according to the contemporary definition of progressive; rather, one should consider what the progressive meant in the appropriate context. Progressivism here refers to a popular political movement of the late 19th and early 20th centuries that targeted monopoly business power, corruption in government, and widespread public immorality. ${ }^{5}$ Although the movement briefly organized for presidential campaigns, progressives on the national stage generally operated as factions within both the Democratic and Republican parties (Link 1971). Political historians generally view Theodore Roosevelt's death and America's entry into World War I as the end of the Progressive Party (Mowry 1946, 377). By 1920, however, progressives had already succeeded in passing much of their legislative agenda, leaving the movement at a crossroads without formal organization (Link 1971, 155). ${ }^{6}$ Nevertheless, national politicians carried the progressive banner well into the 1920s and 1930s (Link 1971; Milkis 2009, 281). When Hoover took office, Progressives were a "sizable and cohesive pro-reform group with relatively stable membership" that met before sessions, shared research services, and tried to maintain unity of policy, strategy, and tactics (Olssen 1980, 246-47). There was a substantial liberal wing of the Republican Party in Congress during the Hoover administration, particularly in the Senate. These progressives, headed by Senator Robert LaFollette Jr. of Wisconsin, largely hailed from Midwestern farm states as did the Iowa-born Hoover.

What issues set progressive and conservative legislators apart during the 1920s and 1930s? Not surprisingly, these groups clashed over economic policy. Progressives advocated large-scale government programs to develop resources, including electric power, while conservatives favored private-sector development. Progressives advocated more direct and aggressive measures to alleviate hardship during the depression than conservatives did (Oulahan 1931). Progressives and conservatives maintained diametrically opposed views on the legal rights of corporations and labor unions, which led to repeated battled over judicial appointments. It is important to note that progressives at this time supported a number of social reforms that may not be considered progressive today, such as prohibition and curtailing the foreign-born population. As Professor Link $(1971,161)$ observed: "The fact that this movement was motivated in part by racism, nativism, and anti-Semitism ... should not blind us to the fact that it was also progressive."

Putting Hoover in the proper political context is somewhat complicated by the fact he did not hold elected office before the Republican Party nominated him to be president. He captured national attention as member of a Democratic president's 
Cabinet. It has been suggested that the Democratic Party even courted the popular Hoover before the 1920 presidential election.

\section{ESTIMATING PRESIDENTIAL IDEAL POINTS}

Political scientists have developed effective methods of comparing the preferences of decision makers, but for the reasons discussed in this section, Hoover has thus far eluded such comparisons. Before applying these tools to evaluate Hoover's legislative record, it is instructive to briefly review how scholars have estimated presidential ideal points.

A substantial body of political science research undergirds ideal point estimation. Spatial models conceptualize political actors as opting for outcomes nearest their ideal points. ${ }^{7}$ Congressional scholars have analyzed roll call voting in Congress to successfully estimate the ideal points of senators and representatives (especially Clinton, Jackman, and Rivers 2004; Poole and Rosenthal 2007). Accurate maps of actors' ideal points can explain a variety of political moments (for overview of some applied works, see Poole and Rosenthal 2007, Chapter 11). These methods of analyzing political decisions are particularly well suited for studying Hoover's legislative record. Rather than hand-picking facts that suit a particular narrative, we can analyze all available data and see what patterns emerge.

Scholars have estimated ideal points of U.S. presidents relative to senators and representatives by treating presidential requests for legislative action as roll call votes. In this research, the president "votes" yea if he requested legislators to vote yea; if he requested legislators vote nay, the president's vote is coded nay. Early efforts to estimate presidential ideal points relied upon Congressional Quarterly's scorecards of presidential legislative support. $C Q$ has identified presidential positions on roll call votes since the Eisenhower administration. More recently, scholars have analyzed the public positions of presidents who served prior to Eisenhower. Data assembled by Swift et al. (2001) has facilitated historical research on presidential decision making (e.g., McCarty 2009; McCarty and Poole 1995). Swift (2001) and her colleagues comprehensively identified presidential requests corresponding to roll call votes in Congress. As a result of the collective efforts of these scholars, we can now incorporate ideal points of nearly all U.S. presidents into our analysis of American politics.

Herbert Hoover, however, has eluded analysts. Scholars have not ignored Hoover; Hoover's ideological preferences have not been successfully estimated to date because he did not make enough requests on roll call votes during his term to locate his ideal point with sufficient certainty. When an actor casts relatively few votes, it is difficult to pinpoint his or her ideal point. For example, if a legislator predictably votes with his or her party, it may be difficult to say more than which side of the aisle the legislator occupies. Some ideal point estimation methods fix legislator coordinates by minimizing prediction errors; thus, a method like 


\begin{tabular}{|lccccc|}
\hline \multicolumn{5}{c|}{ TABLE } & 1. Hoover Votes Used for Estimation \\
\hline Vote Type & 71 st Senate & 72nd Senate & 71 st House & 72nd House & All Terms \\
Requests & 20 & 8 & 8 & 7 & 43 \\
Signings & 12 & $11(1)$ & $12(3)$ & $16(3)$ & $51(7)$ \\
Vetoes & $6(1)$ & $3(1)$ & $8(1)$ & $7(1)$ & $24(4)$ \\
Nominations & 22 & 6 & 0 & 0 & 28 \\
Treaties & $1(1)$ & 0 & 0 & 0 & $1(1)$ \\
Total Hoover Votes & 59 & 26 & 24 & 26 & 135 \\
Roll Call Votes & 436 & 280 & 103 & 123 & 942 \\
\end{tabular}

Number overlapping requests in parentheses.

NOMINATE requires some voting errors (Poole and Rosenthal 2007, 26-7; see also Poole 2005, 155-57). Poole and Rosenthal's DW-NOMINATE estimates included all legislators who cast at least 25 votes in a term of Congress (2007, 32-33). This generally presents no problem because members of Congress cast hundreds, if not thousands, of roll call votes each session. Because presidents are not typical members, the number of votes used for estimation can become an issue. If too few data points are available, the president's ideal point cannot be estimated; even if the president's record barely surpasses the minimum, the standard error of estimation can be problematic. ${ }^{8}$

Swift et al. (2001) identified 158 requests by Hoover to Congress on specific legislative items. Hoover's legislative requests correspond to 44 roll call votes during his administration: 8 roll call votes in the 71st House, 21 votes in the $71 \mathrm{st}$ Senate, 7 votes in the 72nd House, and 8 roll call votes in the 72nd Senate (see Table 1). These numbers are relatively low, reflecting Hoover's "strange paralysis" with respect to legislative prerogatives (Milkis and Nelson 2003, 262-65; see also Eisinger 2000, 645-49; Schwarz 1974).

Hoover's absence from spatial models of politics is problematic for several reasons. First, Hoover is a significant political figure with a disputed historic legacy. Second, a reliable estimate of Hoover's ideal point facilitates historical research by political scientists. For example, judicial scholars have been unable to estimate ideal points of federal judges appointed by Hoover, which limits their ability to conduct historical analysis of the federal courts. ${ }^{9}$

Recent research has identified some of the issues that arise in estimating presidential ideal points. According to a new study by Treier (2010), estimates based on presidential requests suffer from selection bias. The president can pick his legislative battles; members of Congress, in contrast, are routinely compelled to vote yea or nay on a wide variety of issues. Presidents Clinton and G. W. Bush, Treier found, were likely to request legislative action on exceptionally controversial issues. As a result, Clinton and Bush appear more ideologically extreme based on their legislative requests than a broader sample of their legislative behavior suggests. In addition to presidential requests directed to Congress, Treier suggests that we 
may view the president's signing a bill into law as a "yea" vote and vetoing a bill, a "nay" vote.

Some may object that the president's decision to sign or veto a bill is not simply a matter of his policy preferences but may result from strategic calculations and political pressures (Cameron 2000; Cameron and McCarty 2004). The president may veto a bill he prefers to the status quo to force Congress to pass a bill even more to his liking. Similarly, the president may sign a bill he opposes because he believes a veto would be overridden. Hoover, for example, signed the infamous Smoot-Hawley tariff into law, but he had serious reservations about the bill and it is thought that Hoover would have preferred a more limited tariff (Jeansonne 2012).

The argument that bill signings and vetoes may be strategic and insincere has merit but is not fatal to this analysis. ${ }^{10}$ The president is certainly not the only politician who must consider more than personal preferences before deciding to support or oppose a bill; certainly Senators and Representatives also suffer under multiple constraints and may be pressured to vote against their preferences. On the surface, Hoover's sparse record provides little evidence of strategic behavior. When Hoover announced support for bills that Congress passed, he signed them into law ( 7 cases in the roll call record); when Hoover announced his opposition to bills that Congress passed, he vetoed them (4 cases in the roll call record). In any case, this is a model-building assumption; whether this assumption is useful remains to be seen. Later, I discuss how well a sincere preference model explains Hoover's legislative record and consider whether Hoover voted contrary to his preferences more often than members of Congress did.

Based on Treier's research, we may suspect that Hoover's requests do not accurately reflect the ideological position he generally maintained during his administration. ${ }^{11}$ Later, I offer some evidence that the votes analyzed here are more representative of the roll call record than are Hoover's request votes. It appears that scholars used the request votes produced by Swift et al. (2001) because they were readily available, not because they are the only or best record of presidential preferences. $^{12}$

Two guiding principles emerge from prior research on presidential ideal points. First, we should estimate Hoover's ideal point using a representative sample of roll call votes. In a perfect world, one would estimate Hoover's preferences relative to senators and representatives by recording his votes on all the roll call votes that occurred during his administration. This cannot be accomplished but advises against cherry picking votes for analysis. Second, although one can estimate Hoover's ideal point more precisely with additional votes, it is important to base Hoover's record on clear, expressed preferences. Extrapolating Hoover's position on a particular amendment or procedural tactic based on subsequent events starts the researcher down a slippery slope of subjective judgments. ${ }^{13}$

These guiding principles inform the research design used here to test specific hypotheses about Herbert Hoover. Textbook history provides our null hypothesis: Hoover was a conservative Republican. The critical reappraisals of Hoover's 
presidency furnish the basis for the alternative hypothesis that Hoover was progressive on both economic and social issues. The research design and data used to test these hypotheses are detailed in the next section.

\section{RESEARCH DESIGN AND DATA SOURCES}

We can estimate Hoover's ideal point in relation to representatives and senators using roll call votes that took place in the House and Senate during his administration. My estimation strategy is to code Hoover's vote on every roll call vote in the 71st and 72nd terms of Congress for which a reliable basis exists to determine Hoover's position.

The starting point in this analysis is the data on presidential requests compiled by Swift et al. As discussed above, Hoover did not make a sufficient number of requests in office to estimate his ideal point in DW-NOMINATE; he did not make 25 or more requests in a single term of the House or Senate (see Table 1). Nevertheless, Hoover's legislative requests provide a solid foundation for this analysis.

To supplement Hoover's record of requests, I identify all roll call votes for final passage of bills in the 71st and 72nd Congresses that passed both chambers and compelled Hoover's response. ${ }^{14}$ In these cases, Hoover had the opportunity to endorse or oppose the same bill as Congress. If Hoover signed the bill into law, I coded his vote "yea" on final passage. If Hoover vetoed the bill, I code his vote as "nay" on final passage. ${ }^{15}$ If the House or Senate moved to override the president's veto, I determine that Hoover would vote "nay," preferring that Congress sustain his veto. Bill signings side Hoover with legislative majorities and are therefore inherently moderating; vetoes pit Hoover against majorities and move his ideal point to the extremes. ${ }^{16}$ This suggests using both signings and vetoes in the analysis to balance these opposing forces. In a number of cases, the president's response to legislative action overlapped a request. As mentioned above, seven of Hoover's bill signings were preceded by requests that representatives and senators vote yea; Hoover requested that Congress vote nay on bills four times before vetoing them.

I further supplement Hoover's requests, bill signings and vetoes with roll call votes on nominations and treaties he proposed to the Senate. ${ }^{17}$ I determined that Hoover voted yea on both his nominees and treaties. ${ }^{18}$ Hoover only presented one treaty to the Senate and he requested the Senate vote yea on it. Senate roll call votes on 28 Hoover nominees provide additional data to scale Hoover in relation to senators. Confirmation votes are rarely divisive and may not do much to distinguish Hoover, but these votes should be included to evaluate Hoover against his contemporaries based on a broadly comparable set of roll call votes. ${ }^{19}$

Table 1 summarizes the roll call votes used to estimate Hoover's ideal point; the specific votes used in this analysis are detailed in Appendix A. Although this approach enriches the data used to estimate Hoover's ideal point, Hoover's position 
on the majority of roll call votes during his administration remain unknown. While one may infer that he would have supported or opposed preliminary votes based on his position on final passage, I avoid making these inferences and rely on Hoover's expressed preferences.

In order to compare Hoover to his contemporaries, I merge the roll call voting records of the 71st and 72nd Houses and Senates together following Poole's suggestion (2005, Chapter 6). Chambers and terms are bridged by both rows (individuals) and columns (votes). In addition to legislators who continued in the same chamber from the 71st to 72nd terms, a number of legislators who served in the 71st House subsequently served in the 72nd Senate. Assuming their preferences are stable (for empirical support for this assumption, see Poole and Rosenthal 2007, 96-100), these cross-over legislators help us compare the House and Senate. ${ }^{20}$ Hoover's votes also span the chambers and terms.

I identify a number of instances where the House and Senate voted on the same motion. I determine that the House and Senate had roll call votes on the same conference committee reports one time in their 71 st terms and once more in their 72 nd terms.$^{21}$ Both chambers conducted two roll calls to override presidential vetoes in their 71 st terms and one such vote in their 72 nd terms. ${ }^{22}$ In addition, the chambers voted to pass the same bill or resolution four times in the 71 st Congress and two more times in the 72 nd Congress. ${ }^{23}$ These roll calls are treated as single votes with all senators and representatives divided by the same cutting lines. ${ }^{24}$

Hoover's ideal point is estimated from his roll call votes using W-NOMINATE. This method assumes actors have symmetric, single peaked utility functions and positions them in policy space to minimize the utility lost from voting errors. ${ }^{25}$ This method offers a fair test of Hoover's ideology because it does not require us to identify the liberal or conservative sides of issues; it allows Hoover's record for itself as much as possible. Based on prior research, ideal points are estimated in two dimensions. The primary dimension should estimate the relative liberalism or conservatism of Hoover and members of Congress. ${ }^{26}$ Standard errors of ideal point estimates can be recovered using the parametric bootstrap method suggested by Carroll et al.(2009) and Lewis and Poole (2004). This technique offers a measure of uncertainty that enables hypothesis testing. ${ }^{27}$

How does one operationalize the term "progressive" to evaluate whether a particular politician, like Hoover, was progressive? I use a variety of sources to identify progressive members of Congress and compare the location of their ideal points to Hoover's. Many legislators embraced the progressive label. In March, 1931, Senators Costigan (D-CO), Cutting (R-NM), La Follette, Jr. (R-WI), Norris (R-NE), and Wheeler (D-MT) convened a Progressives' Conference in Washington, D.C. to organize a legislative agenda and look ahead to the 1932 election. ${ }^{28}$ The New York Times (1931b) published a list of progressive Senators and Representatives who attended the Conference. In addition to the Progressive Conference organizers and attendees, I include several members of Congress who were repeatedly identified as progressives by journalists and political scientists at the time: Senators Borah 
(R-ID) and Nye (R-ID), and Representatives Howard (D-NE) and LaGuardia (RNY) (New York Times 1930a, 1931c, 1931d, 1931e; MacMahon 1930a, 1930b, 1931; Herring 1932). Finally, historians also identify Senator Brookhart (R-IA) as a progressive member of Congress (MacKay 1972; Milkis 2009; Mowry 1946). If Hoover and these progressive legislators were birds of the same feather, they should have voted together.

I conduct some auxiliary analysis to assess how robust my primary results are to variations on my research design. First, I consider what effect the mix of votes used to estimate Hoover's ideal point has on this analysis. Specifically, I compare an estimate derived from his requests only to the estimate determined from all types of votes. Second, I evaluate the results using difference scaling methods, including Optimal Classification and IDEAL.

\section{RESULTS OF ESTIMATION}

Figure 1 plots President Herbert Hoover's ideal point in relation to members of the 71st and 72nd terms of Congress. As one might suspect, Republicans in the House and Senate are generally more conservative than their Democratic colleagues. Progressives of both parties are located on the left/liberal side of Congress. The Republican majority in these terms is quite heterogeneous. Some of the most liberal members of the 71st and 72nd Senate are Republicans.

These plots provide some initial evidence as to Hoover's position within the Republican Party but we can analyze this question in more detail. To this end, I evaluate Hoover in relation to other Republican Party members. Figure 2 offers density plots of Democrats and Republicans in the House and Senate during the Hoover administration with Hoover's ideal point indicated.

Figure 2 panel (b) shows the bi-modal distribution of Republican senators' ideologies. As discussed, there were a number of progressive Republicans in the Senate at this time. Although progressive Republicans were a force in Congress, Hoover was ideologically distant from them. Hoover appears near the mode of Senate Republicans; however, Hoover is significantly to the right of the Senate Republican mean.

Figures 1 and 2 suggest that Hoover was a conservative Republican. The standard errors calculated through the parametric bootstrap method allow us to test our hypotheses. Specifically, we can ask, what is the probability that Hoover was a typical Republican based on his legislative record? Based on Hoover's ideal point estimate and standard error $(0.610+/-0.147)$, one is confident that Hoover was more conservative than the average Republican in Congress during his administration $(p$-value $=.020)$. Similarly, one is confident that Hoover was more conservative than the median member of his party in Congress $(p$-value $=.026) .{ }^{29}$ At the $95 \%$ confidence level, one rejects the hypothesis advanced by revisionist historians that Hoover was progressive as well as the more modest hypothesis that Hoover was a typical Republican. ${ }^{30}$ 
FIgURE 1. Hoover's Ideal Point in Relation to 71st and 72nd Congresses (color figure available online).

(a) 71st House

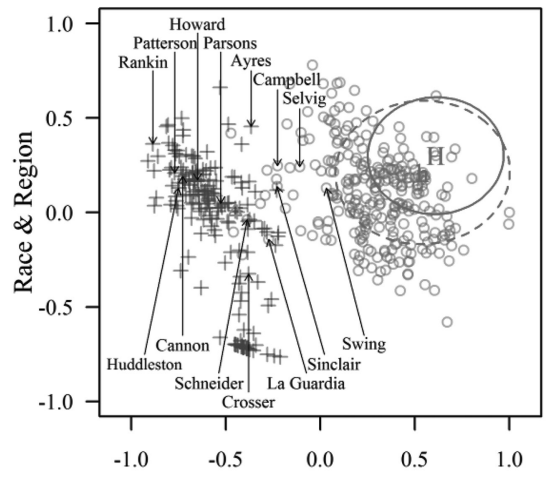

(c) 72nd House

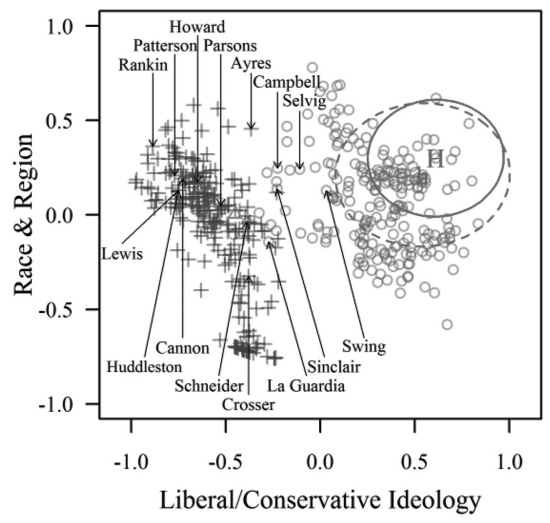

(b) 71st Senate

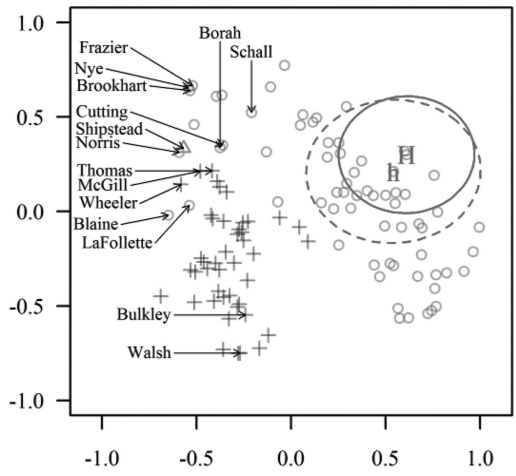

(d) 72nd Senate

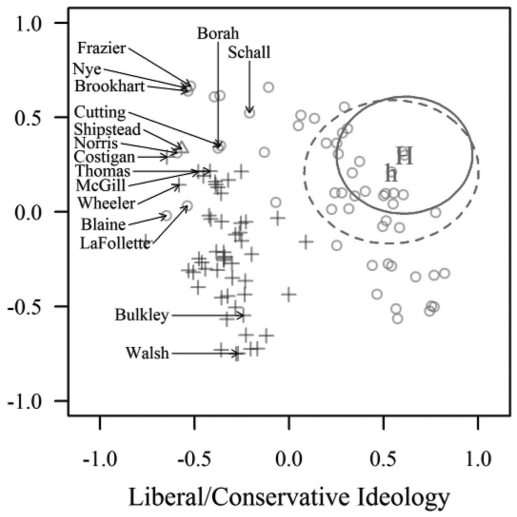

In the 71st and 72nd Congresses, the legislators' placement on the primary dimension explains $82.0 \%$ of their votes $(48.6 \%$ reduction in errors compared to modal predictions); their alignment on the second dimension explains as additional $3.6 \%$ of their votes $\left(58.9 \%\right.$ reduction in prediction errors) ${ }^{31}$ Hoover's ideal point in the spatial model depicted in Figure 1 explains $93.4 \%$ of votes attributed to him. Interestingly, Hoover's decisions are better explained by the spatial model than are the decisions of most members of Congress; this suggests the president's decisions to sign or veto bills were not frequently strategic and insincere, at least no more so than were votes in Congress. Although Hoover is thought to have reluctantly signed the Smoot-Hawley tariff into law (Jeansonne 2012), the House vote to agree 
FIGURE 2. Hoover Relative to Distribution of House and Senate Ideologies (color figure available online).

(a) House of Representatives

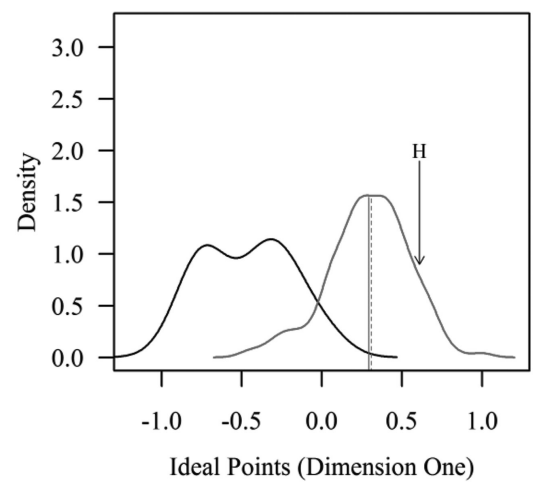

(b) Senate

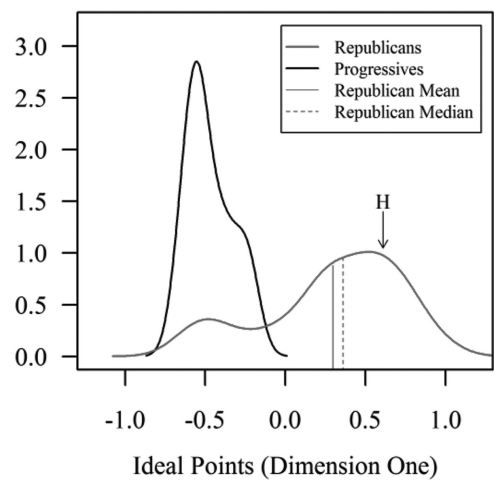

to the conference committee report (vote no. 60 in the 71st House) neatly divided representatives on the primary ideological dimension (the cutting line angle was $\left.96.5^{\circ}\right)$. Nearly all progressives and Democrats voted against the report. Hoover's estimated ideal point is on yea side, relatively far from the cutting line; the spatial model of this vote suggests Hoover's decision to sign the bill into law was consistent with his preferences. ${ }^{32}$

Although roll call voting in these terms had some multi-dimensional quality, I focus here on the primary dimension as it relates to Hoover's asserted progressivism on core issues. Later, I discuss the fact that Hoover and progressive legislators are similar on the second dimension. Restricting the scaling routines to one dimension does not change the results in any appreciable way; presenting ideal point estimates in two dimensions allows one to identify particular individuals like Hoover and known progressives among many actors.

\section{ROBUSTNESS CHECKS}

In this section, I conduct auxiliary analysis of my primary results to assess whether my conclusions are dramatically affected by the composition of votes analyzed or scaling method used to estimate Hoover's ideal point. I compare an estimate based solely on Hoover's requests to that derived from Hoover's complete legislative record. Along similar lines, I consider whether the results reported above are driven by Hoover's foreign policy decisions. I then evaluate the results using difference scaling methods, including Optimal Classification and IDEAL.

One can estimate an actor's ideal point based on subsets of votes to test theories about agenda setting effects (Poole 2005, Chapter 6). In light of past research, one 


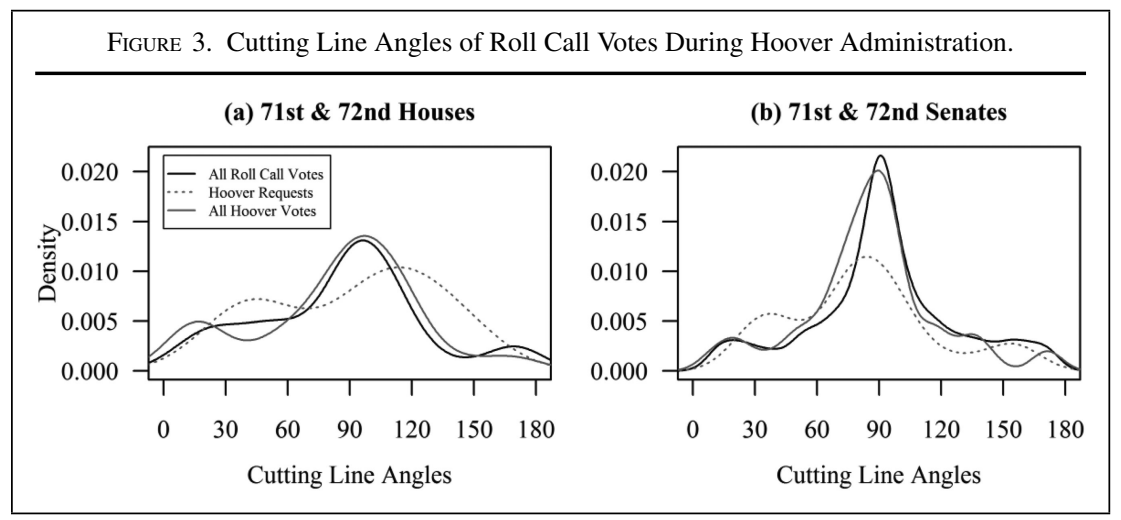

wonders whether the present results are a product of adding votes to Hoover's record of requests. For this analysis, Hoover's roll call voting record is restricted to the 43 requests he made during his administration and scaled using W-NOMINATE. ${ }^{33}$ In Figure 1, Hoover's ideal point based on requests only is indicated by " $h$ " and the $95 \%$ confidence region of this estimation, by a dashed ellipse. Because this estimation is based on fewer observations, the standard error is larger. Although the confidence region of the ideal point estimated from Hoover's complete voting record overlaps that generated from his requests, the point estimate from requests is more moderate than that reflecting his full voting record .541 compared to .610). If one restricts analysis to Hoover's requests, one still confidently rejects the revisionists' claim that Hoover was predominately progressive. However, given the large standard error of estimation, one could not confidently reject the hypothesis that Hoover was a typical Republican.

In addition to reducing uncertainty, enlarging the set of votes used to estimate Hoover's ideal point may yield a more accurate point estimate compared to estimating his ideal point on the basis of his requests only. Hoover's ideological position relative to members of Congress is more likely at " $H$ " than " $h$ " in Figure 1 because the enlarged set of votes that yields " $\mathrm{H}$ " is representative of the underlying roll call record used to locate members of Congress while his request votes are not. The difference in these sets of votes is borne out by comparing the distributions of their cutting lines to that of the full roll call record (for similar analysis, see Bertelli and Grose 2011, 771). ${ }^{34}$

Figure 3 shows that Hoover's request votes (the dotted line) were not representative of roll call voting in Congress during his administration (the black line). Incorporating additional data points in the form of Hoover's nominees, bill signings, and vetoes yields a sample of votes (the solid gray line) that better reflects the roll call record than do Hoover's request votes. Statistical tests support the visual evidence; a random sample of roll call votes could yield a distribution of cutting line angles like the gray line (all presidential votes) in Figure 3, but not a distribution like the dotted line (request votes). ${ }^{35}$ 
The effect of restricting estimation to Hoover's requests is interesting in light of Treier's (2010) finding that estimating the ideal points of Presidents Clinton and G. W. Bush based on their requests (excluding their bill signings and vetoes) makes them appear more ideologically extreme than their full records indicate. While those presidents may have requested legislative action on controversial votes, Hoover apparently made requests on less controversial matters and thus appears more moderate from requests than his full legislative record indicates. This suggests that presidents' use of requests has changed over time or varies from one administration to the next, an interesting development in the exercise of presidential powers. Although the direction of the effect found here is opposite that reported by Treier (2010), this research strongly supports his argument that examining presidents' full voting records better estimates presidents' ideal points than does limiting such analysis to presidential requests.

What if Hoover's foreign policy decisions are excluded? This seems reasonable because contemporary debates focus on Hoover's domestic policies. ${ }^{36}$ To check whether foreign policy positions caused the analysis to classify Hoover as a conservative, I scale Hoover's domestic policy votes only using W-NOMINATE (not shown) and compare the results to Figure 1. Hoover's estimated ideal point based on domestic issues is substantively similar to the estimate derived from all of his known positions ( 0.600 compared to 0.610$)$. The primary results presented here are not driven by Hoover's foreign policies.

To what extent is the analysis of Hoover offered here the result of using WNOMINATE to scale Hoover against his contemporaries rather than another scaling method, such as Poole's (2005, Chapter 3) Optimal Classification or the approach suggested by Clinton, Jackman, and Rivers (2004) (hereafter "IDEAL"). To answer this question, I estimate Hoover's ideal point using these alternate scaling methods.

Optimal Classification (OC) is a non-parametric scaling method that positions actors in policy space to minimize the number of misclassified votes. It does not make assumptions about the specific shape of actors' utility functions (i.e., bellcurved or quadratic) and therefore is an extremely robust method of estimation. I use OC to estimate Hoover's ideal point relative to his contemporaries in the 71st and 72nd Congresses and display the results of this analysis in Appendix B. The results of this analysis are consistent with the results of W-NOMINATE scaling. Hoover is decidedly conservative compared to House Republicans, but flanked on the right by a number of Republican senators. Because OC is a non-parametric scaling method, one cannot recover standard errors for hypothesis testing. One can, however, consider where Hoover falls in a ranking of Republicans from most liberal to most conservative. Hoover would rank as the $346^{\text {th }}$ most liberal Republican in Congress during his administration (out of 372 Republicans). Using OC, the difference between Hoover's ideal point based on his requests only compared to his full record is modest (.452 compared to .509).

I estimate ideal points for Hoover and members of Congress using the function IDEAL from the R library pscl. This scaling method is similar to fitting educational 
testing data via an item-response model and uses Markov Chain Monte Carlo simulations to estimate parameters (Clinton, Jackman, and Rivers 2004). Every $100^{\text {th }}$ MCMC iteration is recorded after a burn-in of 10,000 iterations to produce a sample of 1,000. The ideal points estimated by this method for the 71st and 72nd Houses and Senates are plotted in Appendix C. The spatial map produced by IDEAL is consistent with maps produced by W-NOMINATE and OC. The progressive wing of the Republican Party is clearly visible in the Senate. IDEAL scaling discloses more division on regional and racial issues in the House compared to the Senate. ${ }^{37}$ This method also places Hoover on the conservative side of the Republican Party. The mean ideal point of congressional Republicans during Hoover's administration is outside the 95\% credibility interval for Hoover's ideal point (see solid ellipses in Appendix C); thus, we may reject the hypotheses that Hoover was a progressive or mainstream Republican. IDEAL scaling provides additional evidence that Hoover was a conservative Republican.

\section{DISCUSSION OF RESULTS}

This research informs our understanding of Herbert Hoover's administration. A number of scholars have called into question textbook accounts of Hoover's political ideology and argued that he was a progressive president. I identify Hoover's known positions on roll call votes in the 71st and 72nd Congresses and estimate Hoover's ideal point using W-NOMINATE. My results indicate that Hoover was significantly more conservative than his Republican colleagues. The evidence strongly suggests Hoover was not progressive and that the revisionist accounts of his presidency, however intriguing, do not explain his actions as president. ${ }^{38}$

In this section, I hope to identify legislative acts that put Hoover in the company of conservative Republicans. Did the issues that divided progressives and conservatives during this time period set Hoover apart from his colleagues in Congress? Votes that pitted Hoover and a minority of Republicans against the supermajorities in the House and Senate push him to the extreme right side of the policy space depicted in Figures 1 and 2. Here, one can use spatial models to gain insights into political history.

Hoover staked relatively extreme positions on a number of roll call votes related to military veterans. During the 71st Congress, Hoover vetoed Senate Bill 476 that expanded pension eligibility for veterans. The House voted 229-14 to override Hoover's veto; the Senate, 61-18 against Hoover. During the same term, Hoover vetoed House Resolution 17054 which increased the loan basis of service certificates for veterans. HR 17054 passed the House 363 to 39 and the Senate 72 to 12 and both chambers again voted to override Hoover's veto. These votes are remarkable because Hoover's party controlled both the House and Senate in the 71st Congress. Hoover staked extreme positions against veterans' relief which few progressives or mainstream Republicans supported. If Hoover's positions on 
roll call votes on veterans' issues are excluded from analysis, his ideal point (first dimension) shifts from .610 to .334 , landing him near the center of the Republican Party (see Figure 2). ${ }^{39}$

Although one tends to think that Congress gives the president a great deal of latitude to make appointments (Krutz, Fleisher, and Bond 1998), Hoover's nominees precipitated a number of intense ideological battles in the Senate. Consider, for example, Hoover's nominees to the Federal Power Commission. Progressive legislators wanted the federal government, not the private sector, to develop electricity supplies. Hoover's nominee to head the Commission, George Smith, however, expressed "very definite opposition" to government ownership (New York Times 1930c). ${ }^{40}$ After confirming Smith and Hoover's other nominees, the Senate attempted to rescind its confirmation votes and the appointees filed suit to take their seats (New York Times 1931a). The Supreme Court ultimately sided with Smith. ${ }^{41}$ Although Hoover and progressive were unified in support of creating the Federal Farm Bureau early in the 71st Congress, progressives opposed Hoover's nominees to the Board on the grounds that they represented upper-class interests rather than farmers (New York Times 1929, 1). Hoover's conservative selections for the Supreme Court also caused intense ideological conflicts. Progressive senators passionately opposed the confirmation of Charles Hughes, Hoover's pick for Chief Justice, and defeated the confirmation of John Parker (New York Times 1930b, 1; Oulahan 1930, 53).

What about the second dimension? Referring again to Figure 1, Hoover and most of the progressives have positive y-axis values. This result suggests that Hoover sided with progressives, at least on some issues. There appear to be three policies on which Hoover and the progressives were in agreement: restricting immigration, upholding prohibition, and protecting farm prices. ${ }^{42}$ During the 71 st Congress, Hoover and progressive legislators were together on five roll call votes advancing legislation to protect native wages against immigrant labor and two roll call votes to supplement alcohol prohibition laws in the District of Columbia. ${ }^{43}$ Hoover and the progressives also united to establish a Federal Farm Board (progressives later opposed Hoover's nominees for the Board) as well as a measure to protect dairy farmers by regulating the manufacture and importation of oleomargarine. These votes to protect agriculture are indicative of cross-cutting regional concerns during the Hoover administration. Members of Congress from the Midwest, Deep South, Mid-Atlantic, and West are significantly higher on the second dimension than members from the New England, the Northeast, and Great Lakes regions. These regional differences existed within both parties and in both chambers.

While some social issues appear in the roll call record, progressive social issues clearly did not dominate the legislative agenda during the Hoover administration. The record was dominated by economic issues on which Hoover sided with conservatives rather than progressives. Hoover did not assert his 
supposedly progressive views on civil rights (Grothaus 1984) and environmental protection (Hatfield 1987) on the legislative record during his administration, nor were these issues clearly part of the progressive agenda at that time. ${ }^{44}$

\section{CONCLUSION}

In this article, I consider the claim advanced by contemporary political historians that Herbert Hoover was a progressive president. According to these accounts, textbook American political history should be revised to credit (or blame, depending on the source) Hoover for the New Deal. Political science methods are uniquely suited to inform this important debate.

I complete a roll call voting record for Hoover using House and Senate votes on his nominations, bills he signed and vetoed, a treaty, as well as votes where Hoover requested legislators vote yea or nay. This research fills a gap in presidential research and shows that the revisionist accounts of the Hoover administration are wrong. Although there were progressive members of the Republican Party during the Hoover administration, Herbert Hoover was not one of them. If we analyze Hoover's record in office, it appears that Hoover was significantly more conservative than the average member of his party. I consider the extent to which the conclusions drawn here result from the set of voted analyzed or the method of scaling employed and find that some models indicate Hoover was not significantly more conservative than his fellow Republicans. No research design, however, yields the result that Hoover was progressive; the conclusion presented here may be considered robust.

Prior works were unable to estimate Hoover's ideal point because he made relatively few requests for legislative activity. My research demonstrates a solution to this problem which improves our understanding of presidential behavior. This research may reassure students of American political history that textbook accounts of Hoover as a staunch conservative are largely correct. Successfully estimating Hoover's ideal point may make this fascinating period of American politics more amenable to scientific analysis. Although Hoover needs, and perhaps deserves, a public image make-over, this research suggests efforts to recast him as a progressive Republican are misguided.

Although this research focuses on a particular administration, the method used here to estimate Hoover's ideal point may contribute to presidential studies generally. My work on Hoover demonstrates that a presidential ideal point can be estimated using bill signings, vetoes, nominations, and treaties in addition to requests. This approach allows us to estimate the ideal point of a president, such as Hoover, who made few requests and test controversial hypotheses about his presidency. Enriching the data used to estimate ideal points of presidents generally may yield more accurate and certain ideological measures, a useful contribution to many studies of the presidency. 


\section{NOTES}

1. Campaigning for re-election, President Obama invoked Hoover to criticize Governor Romney's economic plan: "We have tried that, by the way. We tried it for 10 years. It's part of what got into the mess that we're in. It doesn't work. It didn't work for Herbert Hoover, when it was called trickle-down economics during the Depression" (Washington Post 2011).

2. The argument that Hoover was actually a progressive politician is based in part on his personal values and moral beliefs. My analysis is confined to his legislative record while president, years which represent "only a slice of his life" (Jeansonne 2012, xix), rather than what he did before becoming president (e.g., Clements 2010; Nash 1983, 1988, 1996). Although I disagree with the view that Hoover was politically progressive, his biographers reveal his complexity and the incredible challenges he faced while serving his country.

3. Similarly, according to Jeansonne (2012, xix): "The image of Hoover that permeates the public mind is a paradox."

4. The president's telegenic granddaughter, Margaret Hoover, appears frequently on television to comment on political events and has authored a book, American Individualism (2011), the same title as Herbert Hoover's 1923 volume. According to her web site, she is "committed to renewing the Republican Party."

5. One should distinguish the political identifier Progressive from the adjective progressive just as one distinguishes Democratic and Republican legislators from democratic and republican values.

6. The Progressive Party did field a presidential candidate in 1924, Senator Robert La Follette, Sr. The Party's platform declared: "The great issue before the American people is control of government and industry by private monopoly" (MacKay 1972, 143). La Follette captured 16\% of the popular vote.

7. If the reader is unfamiliar with this concept, Shepsle and Bonchek (1997, Chapter 5) provide an excellent introduction to spatial models of political decisions (also see Poole and Rosenthal 2007, Chapter 2). One may intuit an actor's ideal point as identifying his or her preferred location on spectrum of political views extending from one extreme to another. The framework used here facilitates this intuitive interpretation. Negative numbers are on the left side of a number line, zero in the middle, and positive numbers on the right. Accordingly, the primary dimension of interest here ranges from -1 (extremely liberal) to +1 (extremely conservative).

8. It is possible to estimate Hoover's ideal point from a relatively small number of votes using Bayesian methods or by overriding the recommended setting for NOMINATE scaling. These alternative methods offer a solution to the "small N" problem discussed in text and will be used to check the robustness of the findings here, but the uncertainty of these estimations is relatively large and they may be biased if the sample used is not representative of the underlying roll call record.

9. I am referring here to the method of estimating the ideal points of federal judges suggested by Giles, Hettinger, and Peppers (2001). In this approach, a judge's ideal point is derived from the ideal points of the political actors responsible for his or her appointment. Should a vacancy arise in jurisdiction represented by a senator in the president's party, presidents are thought to exercise senatorial courtesy and allow that state's senator(s) to select the nominee. Hoover, however, appointed 34 judges to the federal bench in states without Republican senators and their ideal points cannot be calculated by this standard method.

10. It is not my contention that presidents' decisions to sign or veto legislation always reflect their sincere preferences and are never strategic. Whether and to what extent bill signings and vetoes are explained as sincere voting can and should be subject to empirical analysis. Indeed, spatial models of voting which assume sincere voting behavior can help the researcher identify strategic behavior as errors in a preference model. For example, we might detect strategic behavior when the resident's ideal point puts him on the nay side of a passage vote but he proceeds to sign the bill.

11. The empirical question whether estimating Hoover's ideal point from his legislative requests only explains his other policy decisions is pursued following the main results of this article as a robustness check. I find that votes Hoover requested were more moderate than the legislative decisions he was compelled by Congress to make, particularly with respect to veterans' relief measures.

12. In some instances, we may want to explain presidential position taking in which case his requests furnish the best evidence of his preferences. On other occasions, such as the present, we may want to assess a president's legislative record based on a broader sample of roll call votes.

13. For example, the 71 st Senate conducted 154 roll call votes on motions to amend the Smoot-Hawley Tariff as senators attempted to protect their native industries before finally passing the amended bill. The House and Senate then reconciled their differences through conference, but only the House voted by roll on the 
conference committee report (vote no. 60). Hoover did not request yea or nay votes on any floor amendments but did sign the bill into law. Therefore, I only code Hoover's vote on the bill as finally passed by the House. Accordingly, this estimation of Hoover's ideal point does not hinge on whether he sincerely supported the Smoot-Hawley tariff.

14. As the reader may discern from the vote descriptions included in Appendix A, a chamber's vote to pass a bill is not necessarily its final passage vote. Final passage may occur when one chamber agrees to the other chamber's amendments or insists the other chamber accept its amendments to the bill. In some cases, a chamber finally passes a bill by voting on a conference committee's report. Frequently, final passage occurred through a voice vote rather than a roll call vote. If a bill was passed by voice vote, it is not possible to compare Hoover's decision to sign or veto the bill to yea or nay votes by members of Congress because the legislature did not record individual yea and nay votes. The absence of routine, non-contentious voice votes from the roll call record is unlikely to bias ideal point estimates. Such votes do not change the relative location of ideal points and are, in fact, dropped by the NOMINATE scaling algorithm.

15. Hoover vetoed 37 bills during his time in office, but that number includes bills that were not passed by roll call votes in the House or Senate. I include Hoover's pocket vetoes as nay votes. A question arises whether pocket vetoes should be considered "nay" votes. Pocket vetoes occurred by inaction but one assumes that the president acts purposefully to defeat bill by refusing to sign it in a timely manner.

16. Additionally, controversial bills that fail to attain majority support do not reach the president for his signature or veto. This feature of the legislative process allows the president to avoid taking extreme positions.

17. By constitutional design, nominations and treaties relate the president to the Senate rather than House. Chamber differences would present an issue if I were unable to merge the House and Senate votes together and estimate legislator coordinates at the same time.

18. Additionally, given these nominations were made by Hoover, his vote is coded against procedural motions to defeat his nominees, such as motions to recommit to committee or to reconsider confirmation.

19. If a vote is substantially unanimous, the W-NOMINATE scaling program drops the vote because it will not help distinguish among legislators. In the 71st and 72nd Senates, however, Hoover nominees were rarely confirmed through lopsided votes; a number of Hoover nominees encountered significant opposition.

20. Three Representatives from the 71st House subsequently served in the 72nd Senate: Dickinson (R-IA), Hull (D-TN), and White (R-ME). Robsion (R-KY) served in both the chambers during the 71st Congress. The assumption that their preferences are stable is bolstered by the fact that none of these legislators changed parties moving from one chamber to the other. The results are not noticeably different if the individuals who served in both chambers are omitted and only votes (columns) are used to bridge the two chambers.

21. In the 71st Congress, the House voted on a conference committee report on the Muscle Shoals development project on February 20, 1931 (roll call no. 89); the Senate conducted a roll call vote on the same report three days later (roll call no. 421). In the 72nd Congress, both chambers voted by roll on the conference committee report on a bill broadening the powers of the Reconstruction Finance Corporation (roll call vote no. 76 in the House, no. 205 in the Senate).

22. The House and Senate both voted by roll to override Hoover's veto of a bill for veterans' pensions on June 2, 1930 (House roll call no. 52, Senate roll call no. 342). The following year, the House and Senate both voted by roll to override Hoover's veto of a bill to increase the loan basis of service certificates for veterans (House roll call no. 92, Senate roll call no. 424). In their 72nd terms, the House and Senate had roll call votes to override Hoover's veto of a bill for Philippines' independence (House roll no. 72, Senate roll no. 232).

23. During the 71 st Congress, a number of bills were put to passage votes without amendments in both chambers. The House (roll call vote no. 15) and Senate (roll call vote no. 118) both voted on passage of H.R. 6585 for settlement of French indebtedness, H.R. 1 to establish a Federal Farm Board (House vote no. 2 Senate vote no. 8), H.R. 17054 to increase the loan basis of veterans' service certificates (House vote no. 87, Senate vote no. 418), S.J.R. 3 to amend the Constitution with respect to the timing of congressional sessions (House vote no. 91, Senate vote no. 24), and H.R. 16836 for regulation of oleomargarine (House vote no. 95, Senate vote no. 426). During their 72 nd terms, the House and Senate both voted to pass with amendments H.R. 7726 to pay veterans the face value of their adjusted service certificates (House vote no. 64, Senate vote no. 185) and S.J.R. 211 to repeal the Eighteenth Amendment (House vote no. 112, Senate vote no. 272).

24. Treating votes on conference committee reports and veto override motions as single votes in the House and Senate follows the suggestion of Poole and Rosenthal (2007, 229-230): "Ideally, those roll calls for which the substance was identical in both the House and Senate should be as a single roll call with 535 voters. Examples include veto-override and conference-override votes."

25. The NOMINATE model specifically assumes legislators have normally distributed utility functions. This 
assumption is based on response patterns regularly found in psychological research on choice and perception (see Poole 2005, 90, 198-200 and citations therein). While a single roll call vote only requires the individual to compare two points in the policy space (the yea outcome to the nay outcome), the individual's utility function enables him or her to compare the utility of any two points in the space and make decisions accordingly. I check whether my results are robust to alternate utility functions using Optimal Classification and IDEAL scaling methods.

26. The second dimension (y-axis) generally taps regional differences in voting behavior (generally motivated by race) which are not explained by the primary dimension of ideology. During this time period, prior research identifies regional differences over agriculture and tax policy (Poole and Rosenthal 2007, 57-62).

27. I conduct 500 trials using the W-NOMINATE function in the R library wnominate.

28. Attendees did not break new ground on policy issues, but "the progressives of 1931 found common ground in their uncompromising and unreserved disapproval of the Hoover administration" (MacKay 1972, 254-55).

29. I compare Hoover to the mean and median Republicans in Congress during his administration. If Hoover is compared only to Republicans in the House or Senate, one still rejects the hypothesis that Hoover's ideal point is equal to that of the mean or median Republican with confidence. The substantive conclusions do not change if Hoover is compared to Republicans by chamber by term; he appears more conservative than Republicans in the House and Senate in both the 71st and 72nd terms of Congress. If Hoover is compared to the mean or median progressive (of either party), the $p$-values would be even smaller.

30. I considered this result in light of the uncertainty of the estimate of the Republican mean. Although the mean is estimated from the full population of Republicans, the parametric bootstrap shows there is some uncertainty associated with each individual legislator's ideal point and thus there is some uncertainty estimating the mean. The uncertainty of the mean estimate reflects the varying standard errors of individual legislators. I tested Hoover's ideal point compared to the Republican mean in light of the joint uncertainty of Hoover ideal point and the Republican mean using 1,000 simulated draws of Republican ideal points based on the W-NOMINATE parametric bootstrap results. The uncertainty of the Republican mean is minute; Hoover's ideal point falls to the right of the party mean in over $99 \%$ of cases and the $p$-value of the hypothesis of Hoover equaling the party mean is.009.

31. Given the unusual nature of the times, it is reasonable to ask whether one observes an ideological breakdown in roll call voting during the Hoover administration as a result of contentious executive-legislative relations. I consider this possibility by examining whether the error rate of roll call votes increases over the course of these terms. The data suggest a modest but statistically significant increase in voting errors over this period in both the House and Senate. While there is some evidence of ideological breakdown, the model fit remains relative high; by comparison, the spatial voting model explains roughly $70 \%$ of roll call votes during the party-less Era of Good Feelings (Poole and Rosenthal 2007, Figure 3.1). In addition, roll call votes predominately divided the chambers along one dimension.

32. Consistent with this view, Hoover vetoed a bill to lower tariffs in the 72nd Congress (vote nos. 8 and 49 in the 72nd House). In his veto message to Congress, Hoover declared: "[T]here never has been a time in the history of the United States when tariff protection was more essential to the welfare of the American people than at present" (Hoover 1932). According to Link $(1971,161)$, a revenue tariff was not an authentic progressive objective.

33. For this analysis, I add a row to the roll call vote matrix with Hoover voting consistent with his 44 requests but not participating in other House and Senate roll call votes. This approach is comparable to estimating the ideal point of a member of Congress who left office mid-session and only voted on some fraction of the record.

34. When members vote, one can estimate a cutting line that separates one side of the vote from the other. The W-NOMINATE scaling routine maximizes likelihood by alternatively estimating legislators' ideal points and cutting lines of roll call votes (Poole 2005, 107-10). In a two-dimensional space, the cutting line can be defined in terms of its angle (from the $\mathrm{x}$-axis) and point where it intersects the $\mathrm{x}$-axis. A vote that pits members on the right against those on the left will have an angle close to 90 degrees. In contrast, the cutting line angle for a cross-cutting vote will be closer to 0 or 180 degrees.

35. Because the expected distribution of cutting-line angles is unknown, I use a non-parametric statistical test, the Kolmogorov-Smirnov two-sample test, to test the hypotheses that Hoover's request votes and all Hoover's votes come from the same distribution as the 71st and 72nd Congress roll call votes (for details on this test, see Conover 1999, Chapter 6). This test is useful because it can detect all types of differences between two samples. Given the sample sizes, one rejects the hypothesis that Hoover's request votes have the same 
distribution as the roll call votes because the test statistic exceeds the critical value at $95 \%$ confidence $(.26>$ .18); however, one does not reject the hypothesis that votes analyzed here to estimated Hoover's ideal point have the same distribution because the test statistic is less than the critical value $(.08<.11)$.

36. For this analysis, I consider the issues of tariffs and immigration to be domestic issues because they were raised for domestic considerations. Foreign policy roll call votes include several votes on settling foreign indebtedness to the United States, votes related to Philippines governance, and a treaty vote (see Appendix A).

37. The IDEAL method has a difficult time distinguishing senators on a second dimension during this time period. As the authors advised, "[e]stimation becomes progressively more difficult in higher dimensions" (Clinton, Jackman, and Rivers 2004, 357).

38. Although the present findings are not based on Hoover's post-presidency behavior, Hoover's behavior after leaving office serves to confirm the results of spatial models. After leaving office, Hoover applied his energies to a "prolonged campaign to revive the Republican Party," in part, because he hoped the party would nominate him for president in 1936 and 1940 (Romasco 1984, 143). While this does not exclude the possibility that Hoover was a mainstream Republican, it suggests he was not a member of the progressive minority within the Republican Party.

39. This is not simply a statistical artifact. Relief for veterans was an extremely salient issue during Hoover's term: the conflict between Hoover and the "bonus army" occupied the front page of the New York Times 178 times in 1932 (based on a search for front page news stories containing words "Hoover" and "veterans" in New York Times Historical Database). The administration openly clashed with the "bonus army" of veterans, accused them of harboring communists, and deployed the army to dispel them with force. These events preceded modern opinion polling, but the 1932 campaign and election results suggest these conflicts hurt Hoover's public image (Tugwell 1972). It is interesting to note that President Grover Cleveland is often lauded for vetoing private relief bills for veterans during this administration while Hoover is criticized for making comparable decisions.

40. Another example of this conflict over energy policy is Hoover's veto of a progressive proposal to use government property in Muscle Shoals, Alabama, to produce inexpensive fertilizer and supply electricity for farmers (Link 1971, 160). In his veto message, Hoover expressed his firm opposition to the federal government entering any business in competition with the private sector (Hoover 1931). The roll call record includes five votes on the Muscle Shoals proposal.

41. United States v. Smith, 286 U.S. 6 (1932).

42. I identify these issues by analyzing the cutting lines of roll call votes during the Hoover administration (see Appendix A). Roll call votes on immigration, prohibition, and agriculture met three criteria: they were cross-cutting, they substantially divided Congress, and Hoover and the progressive voted the same way on them.

43. By this time, however, progressives were losing their enthusiasm for prohibition. During the 1931 Progressives' Conference, organizers kept this divisive issue off the agenda.

44. Again, it is important to distinguish between the historic and contemporary definitions of progressive politics. Some progressive social policies from Hoover's day may be considered conservative today (e.g., restricting immigration and prohibiting alcohol) while some issues considered progressive today (like environmental protection and civil rights) were not part of the progressive agenda in Hoover's time.

\section{ACKNOWLEDGEMENTS}

I would like to thank Keith Poole, James Thurber, and the anonymous reviewers for their contributions to this article.

\section{REFERENCES}

Bertelli, Anthony, and Christian Grose. 2011. "The Lengthened Shadow of Another Institution? Ideal Point Estimated for the Executive Branch and Congress." American Journal of Political Science 55: 767-81.

Best, Gary. 1975. The Politics of American Individualism: Herbert Hoover in Transition, 1918-1921. Westwood, CT: Greenwood Press. 
Best, Gary D. 1983. Herbert Hoover, the Postpresidential Years, 1933-1964. Stanford, CA: Hoover Press.

Burner, David. 1974. "Before the Crash: Hoover's First Eight Months in Office.” In The Hoover Presidency: A Reappraisal, eds. Martin Fausold and George Mazuzan. Albany, NY: State University of New York Press, 50-65.

1979. Herbert Hoover: A Public Life. New York, NY: Knopf.

Cameron, Charles. 2000. Veto Bargaining: Presidents and the Politics of Negative Power. New York, NY: Cambridge University Press.

— Political Science 7: 409-35.

Carroll, Royce, Jeffrey Lewis, James Lo, Keith Poole, and Howard Rosenthal. 2009. "Measuring Bias and Uncertainty in DW-NOMINATE Ideal Point Estimates via the Parametric Bootstrap." Political Analysis 17: 261-75.

Ceasar, James. 2011. Designing a Polity: America's Constitution in Theory and Practice. Lanham, MD: Rowan \& Littlefield.

Clements, Kendrick. 2010. The Life of Herbert Hoover: Imperfect Visionary, 1918-1928. New York, NY: Palgrave MacMillan.

Clinton, Joshua D., Simon Jackman, and Douglas Rivers. 2004. "The Statistical Analysis of Legislative Roll Call Data." American Political Science Review 98(May): 355-70.

Conover, W. J. 1999. Practical Nonparametric Statistics, 3rd ed. New York, NY: John Wiley \& Sons.

Continetti, Matthew. 2008. "Here They Come; Democrats Gone Wild." The Weekly Standard 14(7), October 27.

Degler, Carl. 1963. “The Ordeal of Herbert Hoover.” The Yale Review 52. Reprinted in The Shaping of Twentieth Century America (1975), eds. R. Abrams and L. Levine. Boston, MA: Little Brown Co, 353-373.

Eisinger, Robert. 2000. "Gauging Public Opinion in the Hoover White House: Understanding the Roots of Presidential Polling." Presidential Studies Quarterly 30: 643-61.

Evans-Pritchard, Ambrose. 2011. "Europe Has Enshrined 1930s Hooverism into EU Treaty Law." The Daily Telegraph (London). December 12: 5.

Fausold, M. L. (1984). The Presidency of Herbert C. Hoover. Lawrence, KS: University Press of Kansas.

Foster, Peter. 2011. "Hoover Damn." National Post (Canada). October 8 FP19.

Giles, Michael, Virginia Hettinger, and Todd Peppers. 2001. "Picking Federal Judges: A Note on Policy and Partisan Selection Agendas." Political Research Quarterly 54: 623-41.

Grothaus, Larry. 1984. "Herbert Hoover and Black Americans." In Herbert Hoover and the Republican Era: A Reconsideration, eds. Carl Krog and William Tanner. Lanham, MD: University Press of America.

Hatfield, Mark. 1981. Herbert Hoover Reassessed: Essays Commemorating the Fiftieth Anniversary of the Inauguration of Our Thirty-First President. Washington, DC: U.S. Government Printing Office.

. 1987. "Herbert Hoover and the Conservation of Human and Natural Resources." In Understanding Herbert Hoover: Ten Perspectives.,. ed. Lee Nash. Stanford, CA: Hoover Institution Press, 42-52.

Herring, E. Pendleton. 1932. "American Government and Politics: First Session of the SeventySecond Congress." American Political Science Review 26: 846-74.

Hoover, Margaret. 2011. American Individualism: How a New Generation of Conservatives Can Save the Republican Party. New York, NY: Crown Forum.

Hoover, Herbert. 1931. "Veto of the Muscle Shoals Resolution." Public Papers of the Presidents. March 3. Available at http://www.presidency.ucsb.edu/ws/index.php?pid=23008

Hoover, Herbert. 1932. "Veto of a Bill To Amend the Tariff Act of 1930." Public Papers of the Presidents. May 11th. Available at http://www.presidency.ucsb.edu/ws/index.php?pid=23083 
Horwitz, Steven. 2011. "Herbert Hoover: Father of the New Deal." Cato Institute Briefing Papers, No. 122, September 29. Available at http://www.cato.org/pubs/bp/bp122.pdf

Jeansonne, Glen. 2012. The Life of Herbert Hoover: Fighting Quaker, 1928-1933. New York, NY: Palgrave McMillan.

King, Colbert. 2009. “The House's Modern-Day Hoovers.” The Washington Post. January 31, p. A15.

Krutz, Glen, Richard Fleisher, and Jon Bond. 1998. "From Abe Fortas ro Zoe Baird: Why Some Presidential Nominations Fail in the Senate.” American Political Science Review 92: 871-88.

Leuchtenburg, William. 2009. Herbert Hoover: The 31st President, 1929-1933. New York, NY: Times Books.

Lewis, Jeffrey, and Keith Poole. 2004. "Measuring Bias and Uncertainty in Ideal Point Estimates via the Parametric Bootstrap.” Political Analysis 12: 105-27.

Link, Arthur. 1971. "What Happened to the Progressive Movement in the 1920's?" In Progressivism: The Critical Issues, Ed. David Kennedy. Boston, MA: Little, Brown and Company, 147-164.

Lyons, Eugene. 1948. Our Unknown Ex-President: A Portrait of Herbert Hoover. Garden City, NY: Doubleday \& Co., Inc.

MacMahon, Arthur. 1930a. "First Session of the Seventy-First Congress." American Political Science Review 24: 38-59.

. 1930b. "Second Session of the Seventy-First Congress." American Political Science Review 24: 913-46.

- 1931. "Third Session of the Seventy-First Congress." American Political Science Review 25: 932-55.

Matthews, Steve, and Caroline Salas-Gage. 2012. "Obama Mirror Image of Hoover with Lessons from the 1930s." Bloomberg. November 6. Available at http://www.bloomberg.com/ news/2012-11-06/obama-mirror-image-of-hoover-with-lessons-from-1930s.html

McCarty, Nolan. 2009. "Presidential Vetoes in the Early Republic: Changing Constitutional Norms or Electoral Reform?" Journal of Politics 71: 369-84.

— and Legislative Bargaining from 1961 to 1986." Journal of Law, Economics, and Organization 11: 282-312.

MacKay, Kenneth. 1972. The Progressive Movement of 1924. New York, NY: Octagon Books.

Milkis, Sidney. 2009. Theodore Roosevelt, the Progressive Party, and the Transformation of American Democracy. Lawrence, KS: University Press of Kansas.

— and Michael Nelson. 2003. The American Presidency: Origins and Development 1776-2002, 4th ed.. Washington, DC: CQ Press.

Mowry, George. 1946. Theodore Roosevelt and the Progressive Movement. New York, NY: Hill and Wang.

Nash, George. 1983. The Life of Herbert Hoover: The Engineer, 1874-1914. New York, NY: W.W. Norton \& Co.

1988. The Life of Herbert Hoover: The Humanitarian, 1914-1917. New York, NY: W.W. Norton \& Co.

. 1996. The Life of Herbert Hoover: Master of Emergencies, 1917-1918. New York, NY: W.W. Norton \& Co.

. 2003. "Herbert Hoover: Political Orphan.” In Uncommon Americans: The Lives and Legacies of Herbert and Lou Henry Hoover. ed Timothy Walch. Westport, CT: Praeger.

New York Times. 1929. "Senate Confirms Entire Farm Board.” October 17, 1929: 1. . 1930a. "Senator Nye Lauds Tariff Coalition.” January 13, 1930: 2.

. 1930b. "Senate Battles All Day Over Hughes Nomination.” February 13: 1.

1930c. "Dr. Smith Pressed on Power Control." December 12: 20.

. 1931a. "Senate Calls Back Confirmation of 3 on Power Board." January 10: 1.

. 1931b. "Registered for Conference: Many States Represented at Meeting of Progressives."

March 12: 20. 
1931c. "Progressive Rule in House Predicted." October. 25: 3.

1931d. "Progressive Bloc Will Form Friday." November 24: 2.

1931e. "Insurgents Ignore Republican Caucus to Organize Senate.” December 5: 1.

Nice, David. 1984. "The Influence of War and Party System Aging on the Rankings of Presidents." Western Political Quarterly 37: 443-55.

Nichols, Curt. 2012. "The Presidential Rankings Game: Critical Review and Some New Discoveries," Presidential Studies Quarterly 42: 275-99.

Okun, Arthur. 1973. "Comments on Stigler's Paper.” American Economic Review 63: 172-77.

Olssen, Erik. 1980. “The Progressive Group in Congress, 1922-1929.” Historian 42(2): 244-63.

Oulahan, Richard V. 1930. "Senate and the Supreme Court, A New Test: The Rejection of Judge Parker is Regarded as an Important Step in Constitutional History and is Striking Evidence that Liberal Senators Insist on Liberal Members of the Highest Bench.” New York Times, May 11: 53 .

— 1931. "Progressives Call for Extra Session Unless Slump Ends." New York Times. March 13: 1.

Poole, Keith. 2005. Spatial Models of Parliamentary Voting. Cambridge, UK: Cambridge University Press.

Poole, Keith T, and Howard Rosenthal. 2007. Ideology and Congress: A Political-Economic History of Roll Call Voting. New York, NY: Transaction Publishers.

Quigley, David. 2003. "Assessing the Hoover Presidency.” In Uncommon Americans: The Lives and Legacies of Herbert and Lou Henry Hoover, ed. Timothy Walch. Westport, CT; Praeger, 183-191.

Romasco, Albert. 1974. "Herbert Hoover's Policies for Dealing with the Great Depression: The End of the Old Order or the Beginning of the New?" In The Hoover Presidency: A Reappraisal, eds. Martin Fausold and George Mazuzan. Albany, NY: State University of New York Press. - 1984. "Herbert Hoover: The Restoration of a Reputation." Book Review. Reviews in American History 12: 139-43.

Schwarz, Jordan. 1974. "Hoover and Congress: Politics, Personality, and Perspective in the Presidency." In The Hoover Presidency: A Reappraisal, eds. Martin Fausold and George Mazuzan. Albany, NY: State University of New York Press, 87-100.

Shepsle, Kenneth, and Mark Boncheck. 1997. Analyzing Politics: Rationality, Behavior, and Institutions. New York, NY: W.W. Norton and Company.

Spitzer, Eliot. 2011. "Radical, Not Moderate." Slate Magazine. June 16th.

Swift, Elaine K., Robert G. Brookshire, David T. Canon, Evelyn C. Fink, John R. Hibbing, Brian D. Humes, Michael J. Malbin, and Kenneth C. Martis. 2001. Database of United States Congressional Historical Statistics, 1789-1989 [Computer file]. ICPSR03371-v2. Ann Arbor, MI: Inter-university Consortium for Political and Social Research [distributor], 2009-02-03. doi:

Treier, Shawn. 2010. "Where Does the President Stand? Measuring Presidential Ideology," Political Analysis 18: 124-36.

Tugwell, Rexford. 1972. "Roosevelt and the Bonus Marchers of 1932.” Political Science Quarterly 87: 363-76.

Walch, Timothy. 2004. Uncommon Americans: The Lives and Legacies of Herbert and Lou Henry Hoover. Westport, CT; Praeger.

Washington Post. 2011. "In Obama's Words: Obama Delivers Remarks at a Campaign Event in Honolulu, Hawaii," November 14. Available at http://projects.washingtonpost.com/obamaspeeches/speech/855/

Wilson, Joan Hoff. 1975. Herbert Hoover: Forgotten Progressive. Boston, MA: Little Brown.

Ziegler, Robert. 1976. "Herbert Hoover: A Reinterpretation.” Book Review. American Historical Review 81: 800-10. 


\section{APPENDIXES}

\section{Appendix A. Hebert Hoover's "Votes"}

\begin{tabular}{lll}
\hline $\mathrm{HH}=$ Herbert Hoover & Progressives Senators: & Progressive Representatives: \\
$\dagger=$ foreign policy vote & $\mathrm{A}=$ Sen. Blaine & $\mathrm{a}=$ Rep. Ayres \\
$\ddagger \quad$ veterans' aid votes & $\mathrm{B}=$ Sen. Borah & $\mathrm{b}=$ Rep. Campbell \\
& $\mathrm{C}=$ Sen. Brookhart & $\mathrm{c}=$ Rep. Cannon \\
Basis for Coding Hoover's Votes & $\mathrm{D}=$ Sen. Bulkley & $\mathrm{d}=$ Rep. Crosser \\
$\mathrm{R}=$ Request (Swift el. al) & $\mathrm{E}=$ Sen. Costigan (72nd only) & $\mathrm{e}=$ Rep. Howard \\
$\mathrm{S}=$ Signed & $\mathrm{F}=$ Sen. Cutting & $\mathrm{f}=$ Rep. Huddleston \\
$\mathrm{V}=$ Vetoed & $\mathrm{G}=$ Sen. Frazier & $\mathrm{g}=$ Rep. Laguardia \\
$\mathrm{PV}=$ Pocket Vetoed & $\mathrm{I}=$ Sen. LaFollette & $\mathrm{i}=$ Rep. Lewis (72nd only) \\
Nom = Nominated & $\mathrm{J}=$ Sen. McGill & $\mathrm{j}=$ Rep. Parsons \\
$\mathrm{T}=$ Made Treaty & $\mathrm{K}=$ Sen. Norris & $\mathrm{k}=$ Rep. Patterson \\
& $\mathrm{L}=$ Sen. Nye & $\mathrm{l}=$ Rep. Rankin \\
Note: cutting line angles of & $\mathrm{M}=$ Sen. Schall & $\mathrm{m}=$ Rep. Schneider \\
unanimous or near-unanimous & $\mathrm{N}=$ Sen. Shipstead & $\mathrm{n}=$ Rep. Selvig \\
votes cannot be determined & $\mathrm{O}=$ Sen. Thomas & $\mathrm{o}=$ Rep. Sinclair \\
& $\mathrm{P}=$ Sen. Walsh & $\mathrm{p}=$ Rep. Swing
\end{tabular}

(1) 71st Senate Roll Call Votes

\begin{tabular}{|c|c|c|c|c|c|}
\hline No. & Description of Vote & $\mathrm{HH}$ & Basis & $\begin{array}{l}\text { Progressive Senators } \\
\text { ABCDFGIJKLMNOPQ }\end{array}$ & $\begin{array}{l}\text { C.L. } \\
\text { Angle }\end{array}$ \\
\hline 008 & To Pass Federal Farm Board Bill & Yea & $\mathrm{R}$ & YYY-YYY-YYYYYNY & $20.2^{\circ}$ \\
\hline 023 & $\begin{array}{l}\text { To Pass Bill Providing for Censuses and } \\
\text { Apportionment }\end{array}$ & Yea & $\mathrm{R}$ & NYN-YNY - YN- - NYY & $99.9^{\circ}$ \\
\hline 025 & $\begin{array}{l}\text { To Agree to Conf. Comm. Report on } \\
\text { Federal Farm Board Bill }\end{array}$ & Yea & $\mathrm{R}$ & NNN - YNN - NNNNNNN & $94.6^{\circ}$ \\
\hline 026 & $\begin{array}{l}\text { To Agree to Conf. Comm. Report on Bill } \\
\text { Providing for Censuses and } \\
\text { Apportionment }\end{array}$ & Yea & $\mathrm{S}$ & - YN-YNN-NNN-NNN & $115.2^{\circ}$ \\
\hline 027 & $\begin{array}{l}\text { To Discharge Bill to Repeal } \\
\text { National-Origins Provisions of } \\
\text { Immigration Act of } 1924 \text { from Comm. } \\
\text { on Immigration }\end{array}$ & Yea & $\mathrm{R}$ & YYY-NYY-YYYYNYY & $169.4^{\circ}$ \\
\hline 029 & $\begin{array}{l}\text { To Agree to Conf. Comm. Report on } \\
\text { Federal Farm Board Bill }\end{array}$ & Yea & $\mathrm{R}$ & NYY - YYN-YYYYYNN & $96.7^{\circ}$ \\
\hline 058 & Mr. Legge (Federal Farm Board) & Yea & Nom & NYN-YYN-NYY-YYN & $94.7^{\circ}$ \\
\hline 059 & S.R. Mckelvie (Federal Farm Board) & Yea & Nom & NNN-NYN- - YY - YNN & $94.3^{\circ}$ \\
\hline 060 & C. Williams (Federal Farm Board) & Yea & Nom & $\mathrm{NNN}-\mathrm{Y}-\mathrm{N}-\mathrm{NNY}-\mathrm{YYN}$ & $94.8^{\circ}$ \\
\hline 111 & $\begin{array}{l}\text { To Consider Res. Providing for Reduction } \\
\text { of Income Taxes for Calendar Year }\end{array}$ & Yea & $\mathrm{R}$ & NNN - NNN - NNN - NYN & $68.5^{\circ}$ \\
\hline
\end{tabular}
1929 


\section{(1) 71st Senate Roll Call Votes (continued)}

\begin{tabular}{|c|c|c|c|c|c|}
\hline No. & Description of Vote & $\mathrm{HH}$ & Basis & $\begin{array}{l}\text { Progressive Senators } \\
\text { ABCDFGIJKLMNOPQ }\end{array}$ & $\begin{array}{l}\text { C.L. } \\
\text { Angle }\end{array}$ \\
\hline 116 & $\begin{array}{l}\text { To Pass Res. Providing for Reduction of } \\
\text { Income Taxes for Calendar Year } 1929 .\end{array}$ & Yea & $\mathrm{R}$ & NNN-NNN-NNY-NYN & $67.7^{\circ}$ \\
\hline $118 \dagger$ & $\begin{array}{l}\text { To Pass Bill to Authorizing Settlement of } \\
\text { French Indebtedness to U.S.A. }\end{array}$ & Yea & $\mathrm{R}$ & NNY - YNN-NNY - - YN & $81.0^{\circ}$ \\
\hline 119 & Albert L. Watson (Judge, M. Dist. of Pa.) & Yea & Nom & NYN - NNN-NNY - NN - & $83.3^{\circ}$ \\
\hline 120 & $\begin{array}{l}\text { To Recommit Nomination of Richard J. } \\
\text { Hopkins (Judge, Dist. of Kansas) to the } \\
\text { Comm. on the Judiciary }\end{array}$ & Nay & Nom & YNN- -NY-NNN-YYY & $136.4^{\circ}$ \\
\hline 121 & Richard J. Hopkins & Yea & Nom & NYY - - YN-YYY-NNN & $129.4^{\circ}$ \\
\hline 174 & $\begin{array}{l}\text { To Recommit Nomination of Charles E. } \\
\text { Hughes (Chief Justice, SCOTUS) to the } \\
\text { Comm. on the Judiciary }\end{array}$ & Nay & Nom & YYY-YYY-YYNYYNY & $82.9^{\circ}$ \\
\hline 175 & Charles E. Hughes & Yea & Nom & NNN - - NN-NNY - NYN & $84.4^{\circ}$ \\
\hline 184 & $\begin{array}{l}\text { Hugh M. Tate (Interstate Commerce } \\
\text { Comm.) }\end{array}$ & Yea & Nom & $\mathrm{N}-\mathrm{N}-\mathrm{NNN}-\mathrm{NNY}-\mathrm{N}-\mathrm{N}$ & $77.8^{\circ}$ \\
\hline 298 & $\begin{array}{l}\text { To Pass Res. to Create Corp. for the } \\
\text { Operation of Government Properties at } \\
\text { or Near Muscle Shoals, Alabama } \\
\text { (Muscle Shoals Res.) }\end{array}$ & Nay & $\mathrm{R}$ & NYY - YYN-NYYNNNN & $73.1^{\circ}$ \\
\hline 299 & $\begin{array}{l}\text { Herbert B. Crosby (Comm.er, District of } \\
\text { Columbia) }\end{array}$ & Yea & Nom & YYY-YYY-YYYYYYY & $115.9^{\circ}$ \\
\hline 304 & $\begin{array}{l}\text { To Amend Immigration Bill to Provide } \\
\text { that National Origins Provisions of the } \\
\text { Immigration Laws will Remain Intact }\end{array}$ & Nay & $\mathrm{R}$ & $N N Y--N--N Y-Y-Y N$ & $141.8^{\circ}$ \\
\hline 305 & $\begin{array}{l}\text { To Amend Immigration Bill by Repealing } \\
\text { National Origins Provisions and } \\
\text { Reducing in Number the Persons } \\
\text { Entering the U.S. }\end{array}$ & Yea & $\mathrm{R}$ & NNN- - NN-NN-NYNN & $168.7^{\circ}$ \\
\hline 317 & $\begin{array}{l}\text { To Amend Immigration Bill by Striking } \\
\text { Out Repeal of the National Origins } \\
\text { Clause }\end{array}$ & Nay & $\mathrm{R}$ & YYY- -YY-YYYYNYY & $167.7^{\circ}$ \\
\hline 321 & $\begin{array}{l}\text { Judge John J. Parker (Associate Justice, } \\
\text { SCOTUS) }\end{array}$ & Yea & Nom & NNN - YNN - NNNNYNN & $69.0^{\circ}$ \\
\hline 324 & $\begin{array}{l}\text { To Pass Bill Providing for Establishment } \\
\text { of a National Employment System }\end{array}$ & Nay & PV & NNN - NNN - NNNNNNN & $77.0^{\circ}$ \\
\hline $342 \ddagger$ & $\begin{array}{l}\text { To Pass Bill Granting Pensions and } \\
\text { Increase of Pensions to Certain } \\
\text { Soldiers, Sailors and Nurses over Veto } \\
\text { of the President }\end{array}$ & Nay & $\mathrm{V}$ & Y-Y-YYY-YYYYY-Y & $87.0^{\circ}$ \\
\hline $347 \ddagger$ & $\begin{array}{l}\text { To Pass Bill to Amend World War } \\
\text { Veterans Act } 1924\end{array}$ & Yea & $\mathrm{S}$ & YYY-YYY-YYYYYYY & $51.6^{\circ}$ \\
\hline 354 & $\begin{array}{l}\text { To Agree to Conf. Comm. Report on Bill } \\
\text { to Amend Definition of Oleomargarine } \\
\text { Container in } 1886 \text { Trade Act }\end{array}$ & Yea & $\mathrm{S}$ & YYY-YYY-YYYYYYY & $11.4^{\circ}$ \\
\hline 361 & $\begin{array}{l}\text { To Agree to House Amendment to Fiscal } \\
\text { Year } 1930 \text { Approp. Bill }\end{array}$ & Yea & $\mathrm{S}$ & YYY-YYY-YYYYNN- & $132.4^{\circ}$ \\
\hline
\end{tabular}




\section{(1) 71st Senate Roll Call Votes (continued)}

\begin{tabular}{|c|c|c|c|c|c|}
\hline No. & Description of Vote & $\mathrm{HH}$ & Basis & $\begin{array}{l}\text { Progressive Senators } \\
\text { ABCDFGIJKLMNOPQ }\end{array}$ & $\begin{array}{l}\text { C.L. } \\
\text { Angle }\end{array}$ \\
\hline $363 \ddagger$ & $\begin{array}{l}\text { To Agree to Conf. Comm. Report on Bill } \\
\text { to Amend World War Veterans Act } \\
1924\end{array}$ & Yea & $\mathrm{S}$ & $N-Y-N-N-N Y-Y N Y-$ & $95.5^{\circ}$ \\
\hline $373 \dagger$ & $\begin{array}{l}\text { To Pass a Res. of Ratification of Treaty } \\
\text { between Governments of U.S., Great } \\
\text { Britain and Japan (with stipulations) }\end{array}$ & Yea & $\mathrm{R}, \mathrm{T}$ & YYY-YYY-YYYNYNY & $90.0^{\circ}$ \\
\hline 381 & $\begin{array}{l}\text { To Recede from Amendment to Bill } \\
\text { Making Supp. Approp. for Emergency } \\
\text { Construction on Certain Public Works }\end{array}$ & Yea & $S$ & NNNNNNNNNNYNNNN & $96.8^{\circ}$ \\
\hline 384 & $\begin{array}{l}\text { George Otis Smith (Federal Power } \\
\text { Comm.) }\end{array}$ & Yea & Nom & NNNYNNNNNNYNN-N & $82.4^{\circ}$ \\
\hline 385 & Frank R. McNinch & Yea & Nom & YYYYYNYYYY- -Y-Y & $136.5^{\circ}$ \\
\hline 386 & Marcel Garsoud (Federal Power Comm.) & Yea & Nom & NNNYNNNNNN - - Y - N & $71.2^{\circ}$ \\
\hline 388 & $\begin{array}{l}\text { To Reconsider the Confirmation of the } \\
\text { Nomination of George Otis Smith }\end{array}$ & Nay & Nom & YYYYYYYYYY-YYYY & $92.1^{\circ}$ \\
\hline 389 & $\begin{array}{l}\text { To Recall the Res. of Confirmation as } \\
\text { Regards George Otis Smith. }\end{array}$ & Nay & Nom & YYYYYYYYYY - YYYY & $95.0^{\circ}$ \\
\hline 390 & $\begin{array}{l}\text { To Pass Bill Promoting Health and } \\
\text { Welfare of Mothers and Infants }\end{array}$ & Yea & $\mathrm{R}$ & YNYYY-YYYY-NYNY & $22.2^{\circ}$ \\
\hline 392 & Edgar B. Brossard (U.S. Tariff Comm.) & Yea & Nom & NYNNNNNNNNYNNNN & $100.4^{\circ}$ \\
\hline 393 & $\begin{array}{l}\text { To Pass Bill Authorizing Alterations and } \\
\text { Repairs to Certain Naval Vessels }\end{array}$ & Yea & $\mathrm{S}$ & NNNYYNNYNNYYNYY & $76.6^{\circ}$ \\
\hline 396 & $\begin{array}{l}\text { To Recommit the Nominations of Smith, } \\
\text { Garsoud, and Draper to the Interstate } \\
\text { Commerce Comm. }\end{array}$ & Nay & Nom & YYYYYYYYYY-YYYY & $86.2^{\circ}$ \\
\hline 397 & $\begin{array}{l}\text { To Consider Bill Supplementing National } \\
\text { Prohibition Act for the District of } \\
\text { Columbia }\end{array}$ & Yea & $\mathrm{R}$ & NNYNNYNYYY - - YNY & $31.3^{\circ}$ \\
\hline 398 & $\begin{array}{l}\text { To Refer Bill to Supplement National } \\
\text { Prohibition Act for the District of } \\
\text { Columbia to the Comm. on the } \\
\text { Judiciary }\end{array}$ & Nay & $\mathrm{R}$ & YNNYYNYNNN - YNYY & $12.3^{\circ}$ \\
\hline 409 & George O. Smith & Yea & Nom & NNNN-NNNN - - NNNN & $91.2^{\circ}$ \\
\hline 410 & Marcel Garsoud & Yea & Nom & NNNYNNNNN - - NNNN & $88.9^{\circ}$ \\
\hline 411 & Claude L. Draper (Federal Power Comm.) & Yea & Nom & NNYYNNNNN - - NNNN & $83.6^{\circ}$ \\
\hline 412 & $\begin{array}{l}\text { To Agree to Conf. Comm. Report on Bill } \\
\text { Making Approp. for Treasury and Post } \\
\text { Office Depts. }\end{array}$ & Yea & $\mathrm{S}$ & NNNNNNNNNN - NNNN & $98.4^{\circ}$ \\
\hline 415 & $\begin{array}{l}\text { To Pass Bill Providing for Shorter Work } \\
\text { Week for Postal Employees }\end{array}$ & Yea & $S$ & YYYYYYYYYYYYYYY & NA \\
\hline 416 & $\begin{array}{l}\text { To Adopt the Conf. Report on } 1932 \\
\text { Interior Approp. Bill }\end{array}$ & Yea & S & NNNNNNNYNNNNNYN & $65.4^{\circ}$ \\
\hline $418 \ddagger$ & $\begin{array}{l}\text { To Pass Bill Increasing Loan Basis of } \\
\text { Adjusted Service Certificates }\end{array}$ & Nay & $\mathrm{S}$ & YNYYYYYYYYYYYYY & $90.3^{\circ}$ \\
\hline 419 & $\begin{array}{l}\text { To Pass Conf. Comm. Report on Bill } \\
\text { Making Approp. for the Treasury and } \\
\text { Post Office Depts. }\end{array}$ & Yea & $\mathrm{S}$ & $\mathrm{N}-\mathrm{NYNNNYNNYNN-N}$ & $53.4^{\circ}$ \\
\hline
\end{tabular}


B. C. Edwards

(1) 71st Senate Roll Call Votes (continued)

\begin{tabular}{|c|c|c|c|c|c|}
\hline No. & Description of Vote & $\mathrm{HH}$ & Basis & $\begin{array}{l}\text { Progressive Senators } \\
\text { ABCDFGIJKLMNOPQ }\end{array}$ & $\begin{array}{l}\text { C.L. } \\
\text { Angle }\end{array}$ \\
\hline 421 & $\begin{array}{l}\text { To Agree to Conf. Comm. Report on } \\
\text { Muscle Shoals Res. }\end{array}$ & Nay & $\mathrm{R}, \mathrm{V}$ & YYYYYYYYYYYYYYY & $77.6^{\circ}$ \\
\hline 422 & Eugene Meyer (Federal Reserve Board) & Yea & Nom & NYNYYNNN-N-YNY- & $70.5^{\circ}$ \\
\hline $424 \ddagger$ & $\begin{array}{l}\text { To Pass Bill to Increase Loan Basis of } \\
\text { Adjusted Certificates over Veto of the } \\
\text { President }\end{array}$ & Nay & V & YNYYYYYYYYYYYYY & $92.7^{\circ}$ \\
\hline 426 & $\begin{array}{l}\text { To Pass Bill To Amend } 1886 \text { Trade Act } \\
\text { Concerning Oleomargarine }\end{array}$ & Yea & S & YYYYYYYYYYYYYYY & $117.8^{\circ}$ \\
\hline 430 & $\begin{array}{l}\text { To Discharge Res. from Comm. On } \\
\text { Immigration }\end{array}$ & Yea & $\mathrm{R}$ & $\mathrm{NN}-\mathrm{NN}-\mathrm{NY}-\mathrm{N}-\mathrm{NY}--$ & $81.0^{\circ}$ \\
\hline 432 & $\begin{array}{l}\text { To Suspend Rules to Consider Res. to } \\
\text { Restrict Immigration into the U.S. }\end{array}$ & Yea & $\mathrm{R}$ & NN-NN-NY-NN-Y- - & $119.9^{\circ}$ \\
\hline 435 & $\begin{array}{l}\text { To Consider Conf. Report on Bill } \\
\text { Promoting Health and Welfare of } \\
\text { Mothers and Infants }\end{array}$ & Yea & $\mathrm{R}$ & $\mathrm{Y}-\mathrm{-N}-\mathrm{YYYYYYNYNY}$ & $21.6^{\circ}$ \\
\hline 436 & $\begin{array}{l}\text { To Pass Muscle Shoals Res. over Veto of } \\
\text { the President }\end{array}$ & Nay & V & YYYYYYYYYY-YYYY & $78.1^{\circ}$ \\
\hline
\end{tabular}

(2) 72nd Senate Roll Call Votes

\begin{tabular}{|c|c|c|c|c|c|}
\hline No. & Description of Vote & $\mathrm{HH}$ & Basis & $\begin{array}{c}\text { Progressive Senators } \\
\text { ABCDEFGIJKLMNOPQ }\end{array}$ & $\begin{array}{l}\text { C.L. } \\
\text { Angle }\end{array}$ \\
\hline $029 \dagger$ & $\begin{array}{l}\text { To Pass Res. Authorizing Postponement } \\
\text { of Payments from Foreign } \\
\text { Governments to U.S. }\end{array}$ & Yea & $\mathrm{R}$ & YYYYYYNYYNNNNNYY & $61.8^{\circ}$ \\
\hline 040 & $\begin{array}{l}\text { To Pass Bill to Provide Emergency } \\
\text { Financing Facilities for Banks and } \\
\text { Other Financial Institutions }\end{array}$ & Yea & S & N-NYYYYNNNY - -NYN & $90.2^{\circ}$ \\
\hline 045 & $\begin{array}{l}\text { To Agree to Amendment to Bill Making } \\
\text { Approp. to Supply Urgent Deficiencies } \\
\text { in Certain Approp. }\end{array}$ & Yea & S & NNNY - - NNYNNN - - N- & $66.2^{\circ}$ \\
\hline 052 & $\begin{array}{l}\text { William E. Humphreys (Federal Trade } \\
\text { Comm.) }\end{array}$ & Yea & Nom & NNNN-NNNN-NYYNNN & $88.8^{\circ}$ \\
\hline 053 & $\begin{array}{l}\text { Harvey C. Couch (Reconstruction } \\
\text { Finance Corp.) }\end{array}$ & Yea & Nom & N-NY - NNNN-NYNYY- & $55.4^{\circ}$ \\
\hline 054 & Ira M. Ornburn (U.S. Tariff Comm.) & Yea & Nom & YYYYN-NNYYNY-YYN & $77.3^{\circ}$ \\
\hline 067 & $\begin{array}{l}\text { To Pass Bill Amending Judicial Code to } \\
\text { Define and Limit Jurisdiction of Courts } \\
\text { Sitting in Equity }\end{array}$ & Yea & $\mathrm{S}$ & YYYYYYYYYYYYYYYY & $55.1^{\circ}$ \\
\hline 080 & $\begin{array}{l}\text { To Recommit Res. to Comm. On Approp. } \\
\text { with Instructions }\end{array}$ & Yea & $\mathrm{R}$ & $\mathrm{N}-\mathrm{N}-\mathrm{N}-\mathrm{N}-\mathrm{NNNNY}---$ & $91.3^{\circ}$ \\
\hline 083 & To Pass Bill Amending Tariff Act of 1930 & Nay & $\mathrm{V}$ & YNYYY - YYYYYN - YY - & $115.1^{\circ}$ \\
\hline
\end{tabular}


(2) 72nd Senate Roll Call Votes (continued)

\begin{tabular}{|c|c|c|c|c|c|}
\hline No. & Description of Vote & $\mathrm{HH}$ & Basis & $\begin{array}{c}\text { Progressive Senators } \\
\text { ABCDEFGIJKLMNOPQ }\end{array}$ & $\begin{array}{l}\text { C.L. } \\
\text { Angle }\end{array}$ \\
\hline 084 & $\begin{array}{l}\text { To Reconsider Rejection of Nomination } \\
\text { of Charles A. Jones (District Attorney, } \\
\text { Western District of North Carolina) }\end{array}$ & Yea & Nom & NYYNNNN-NN-Y-NNN & $133.2^{\circ}$ \\
\hline 153 & $\begin{array}{l}\text { To Pass Bill to Provide Revenue, Equalize } \\
\text { Taxation, and for Other Purposes }\end{array}$ & Yea & $\mathrm{R}$ & N- - YNYYYYYYYN-YY & $99.4^{\circ}$ \\
\hline 164 & $\begin{array}{l}\text { To Pass Conf. Report on Bill To Provide } \\
\text { Revenue, Equalize Taxation, and for } \\
\text { Other Purposes }\end{array}$ & Yea & $\mathrm{R}, \mathrm{S}$ & NNNNNNNNNNNNNNY - & $73.6^{\circ}$ \\
\hline 183 & $\begin{array}{l}\text { To Agree to House Amendment to } 1932 \\
\text { Naval Approp. Bill }\end{array}$ & Yea & $\mathrm{S}$ & N-NYN-NNNNNYNNNN & $85.8^{\circ}$ \\
\hline 188 & T.V. O'Connor (Shipping Board) & Yea & Nom & $\mathrm{N}---\mathrm{N}-\mathrm{NNNN}---\mathrm{NY}-$ & $90.2^{\circ}$ \\
\hline 199 & $\begin{array}{l}\text { To Agree to Conf. Comm. Report on Bill } \\
\text { Making Approp. for the Legislative } \\
\text { Branch }\end{array}$ & Yea & $\mathrm{S}$ & $\mathrm{N}--\mathrm{YNN}-\mathrm{NY}-\mathrm{-N}-\mathrm{Y}--$ & $80.9^{\circ}$ \\
\hline 200 & $\begin{array}{l}\text { To Agree to Amendment to Bill Making } \\
\text { Approp. to Supply Deficiencies in } \\
\text { Certain Approp. }\end{array}$ & Yea & $\mathrm{S}$ & YYYYY-YYYYYYYN- - & $50.7^{\circ}$ \\
\hline 203 & $\begin{array}{l}\text { To Recommit Nomination of Edgar B. } \\
\text { Brossard (U.S. Tariff Comm.) to } \\
\text { Comm. on Finances }\end{array}$ & Nay & Nom & Y-YYY-Y-YYYN-YY - & $92.0^{\circ}$ \\
\hline 205 & $\begin{array}{l}\text { To Agree to Conf. Comm. Report to Res. } \\
\text { to Relieve Destitution, to Broaden the } \\
\text { Lending Powers of the Reconstruction } \\
\text { Finance Corp. and to Create } \\
\text { Employment }\end{array}$ & Nay & $\mathrm{R}, \mathrm{V}$ & NYYNY - YNYYYYNYY - & $107.5^{\circ}$ \\
\hline 212 & $\begin{array}{l}\text { To Table Reconsideration of Passage Bill } \\
\text { Authorizing Supp. Approp. for } \\
\text { Emergency Highway Construction }\end{array}$ & Yea & $\mathrm{R}$ & Y-YYY-NYYYYYYYY- & $44.7^{\circ}$ \\
\hline 217 & $\begin{array}{l}\text { To Insist on Senate Amendments to Bill } \\
\text { to Create Federal Home Loan Banks } \\
\text { (House Agreed to Senate Amendments, } \\
\text { vote no. 86) }\end{array}$ & Yea & $\mathrm{S}$ & -YYNY-YY-YYN-YY- & $76.4^{\circ}$ \\
\hline $232 \dagger$ & $\begin{array}{l}\text { To Pass Philippine Independence Bill over } \\
\text { Veto of the President }\end{array}$ & Nay & $\mathrm{V}$ & YYYYYYYYYYYNYYYY & $86.4^{\circ}$ \\
\hline 233 & $\begin{array}{l}\text { To Order Cloture on Bill for Safer and } \\
\text { More Effective Use of Assets of } \\
\text { Federal Reserve Banks and of National } \\
\text { Banking Associations }\end{array}$ & Yea & $\mathrm{R}$ & NNNYNNNNYNNYNNYN & $26.0^{\circ}$ \\
\hline 239 & $\begin{array}{l}\text { To Pass Bill for Safer and More Effective } \\
\text { Use of Assets of Federal Reserve Banks } \\
\text { and of National Banking Associations }\end{array}$ & Yea & $\mathrm{R}$ & - -NYY-N-Y-NNNN- - & $39.5^{\circ}$ \\
\hline 264 & $\begin{array}{l}\text { To Agree to Amendment Bill Making } \\
\text { Approp. for Military and Non-Military } \\
\text { Activities of the War Dept. }\end{array}$ & Yea & $\mathrm{S}$ & $\mathrm{N}--\mathrm{NNYNNNNN}-\mathrm{N}-\mathrm{NN}$ & $96.1^{\circ}$ \\
\hline
\end{tabular}


B. C. Edwards

(2) 72nd Senate Roll Call Votes (continued)

\begin{tabular}{|c|c|c|c|c|c|}
\hline No. & Description of Vote & $\mathrm{HH}$ & Basis & $\begin{array}{c}\text { Progressive Senators } \\
\text { ABCDEFGIJKLMNOPQ }\end{array}$ & $\begin{array}{l}\text { C.L. } \\
\text { Angle }\end{array}$ \\
\hline 276 & $\begin{array}{l}\text { To Agree to Conf. Comm. Report on } \\
\text { Approp. Bill for Treasury and Post } \\
\text { Office Depts. (Senate later agreed to } \\
\text { Conf. Report without roll call vote, see } \\
\text { Cong. Record 76: 5470). }\end{array}$ & Yea & S & NNYN- - NNNNN-N-NN & $98.7^{\circ}$ \\
\hline 279 & $\begin{array}{l}\text { To Pass Bill to Establish a Uniform } \\
\text { System of Bankruptcy throughout the } \\
\text { U.S. }\end{array}$ & Yea & S & $\mathrm{N}-\mathrm{N}---\mathrm{YYY}-\mathrm{Y}-\mathrm{NYY}-$ & $89.4^{\circ}$ \\
\hline
\end{tabular}

\section{(3) 71 st House Roll Call Votes}

\begin{tabular}{|c|c|c|c|c|c|}
\hline No. & Description of Vote & $\mathrm{HH}$ & Basis & $\begin{array}{l}\text { Progressive Reps. } \\
\text { abcdefgjklmnop }\end{array}$ & $\begin{array}{l}\text { C.L. } \\
\text { Angle }\end{array}$ \\
\hline 002 & $\begin{array}{l}\text { To Pass Bill to Establish a Federal Farm } \\
\text { Board }\end{array}$ & Yea & $\mathrm{R}$ & YYNNYNY-YYYYYY & $20.2^{\circ}$ \\
\hline 011 & $\begin{array}{l}\text { To Pass Bill Providing for Census and } \\
\text { Apportionment }\end{array}$ & Yea & $\mathrm{R}$ & YNYYNNY-NNYYNY & $24.3^{\circ}$ \\
\hline 012 & $\begin{array}{l}\text { To Recommit Bill Providing for Census } \\
\text { and Apportionment to Conf. Comm. } \\
\text { with Instructions }\end{array}$ & Yea & $\mathrm{R}, \mathrm{S}$ & Y-Y-YY- - YYNYYN & $21.5^{\circ}$ \\
\hline 013 & $\begin{array}{l}\text { To Recommit Bill to Establish a Federal } \\
\text { Farm Board with Instructions to Insist } \\
\text { on Striking Out Senate Amendment }\end{array}$ & Yea & S & NNNYNNY - NNNNNY & $75.4^{\circ}$ \\
\hline $014 \dagger$ & $\begin{array}{l}\text { To Pass Res. Related to French } \\
\text { Indebtedness to U.S. }\end{array}$ & Yea & $\mathrm{R}, \mathrm{S}$ & $\mathrm{N}---\mathrm{NN}--\mathrm{NNN}-\mathrm{NY}$ & $76.0^{\circ}$ \\
\hline $015 \dagger$ & $\begin{array}{l}\text { To Pass Bill Authorizing Settlement of } \\
\text { French Indebtedness to U.S. }\end{array}$ & Yea & $\mathrm{R}, \mathrm{S}$ & NYNYNNY-NNNYYY & $81.0^{\circ}$ \\
\hline 017 & $\begin{array}{l}\text { To Pass a Bill Authorizing the President } \\
\text { to Appoint a Comm. to Study and } \\
\text { Report on the Conservation and } \\
\text { Administration of the Public Domain }\end{array}$ & Yea & $S$ & - YNYNNY-NNYYYY & $104.3^{\circ}$ \\
\hline 027 & $\begin{array}{l}\text { To Agree to Conf. Report on Approp. for } \\
\text { the Depts. of State and Justice, } \\
\text { Judiciary, Commerce, and Labor }\end{array}$ & Yea & S & NYNNNNY - NNNY - Y & $89.3^{\circ}$ \\
\hline 028 & $\begin{array}{l}\text { To Pass Bill Authorizing Coinage of } \\
\text { Silver Pieces in Commemoration of } \\
\text { Gadsen Purchase over Veto of the } \\
\text { President }\end{array}$ & Nay & $\mathrm{V}$ & NNNNYNN-YYNNNN & $108.6^{\circ}$ \\
\hline $030 \ddagger$ & $\begin{array}{l}\text { To Pass Bill Amending the World War } \\
\text { Veterans Act of } 1924\end{array}$ & Nay & $\mathrm{V}$ & YYYYYYY-YYYYYY & $115.5^{\circ}$ \\
\hline 045 & $\begin{array}{l}\text { To Pass Bill Providing Living Quarters for } \\
\text { Employees of the Government in } \\
\text { Foreign Countries }\end{array}$ & Yea & S & -Y-YYNY- -NYYNY & $53.0^{\circ}$ \\
\hline
\end{tabular}


(3) 71 st House Roll Call Votes (continued)

\begin{tabular}{|c|c|c|c|c|c|}
\hline No. & Description of Vote & $\mathrm{HH}$ & Basis & $\begin{array}{l}\text { Progressive Reps. } \\
\text { abcdefgjklmnop }\end{array}$ & $\begin{array}{l}\text { C.L. } \\
\text { Angle }\end{array}$ \\
\hline 048 & $\begin{array}{l}\text { To Pass Joint Res. Providing for the } \\
\text { National Defense by the Creation of a } \\
\text { Corp. for the Operation of the } \\
\text { Government Properties at or Near } \\
\text { Muscle Shoals in the State of Alabama }\end{array}$ & Nay & $\mathrm{R}$ & NNNNNNN-NNNNNY & $99.3^{\circ}$ \\
\hline $052 \ddagger$ & $\begin{array}{l}\text { To Pass Bill Granting Pensions and } \\
\text { Increase of Pensions to Certain } \\
\text { Soldiers, Sailors and Nurses over Veto } \\
\text { of the President }\end{array}$ & Nay & $\mathrm{V}$ & YYYYYYY-YYYYYY & $87.0^{\circ}$ \\
\hline 060 & $\begin{array}{l}\text { To Agree to Conf. Comm. Report on Bill } \\
\text { to Provide Revenue and to Regulate } \\
\text { Commerce with Foreign Countries } \\
\text { (The Smoot-Hawley Tariff) }\end{array}$ & Yea & $\mathrm{S}$ & NNNNNNN-NNNNYY & $96.5^{\circ}$ \\
\hline 062 & $\begin{array}{l}\text { To Insist on Disagreement to a Senate } \\
\text { Amendment to } 1931 \text { D.C. Approp. Bill }\end{array}$ & Yea & $S$ & YYYYYYY-NYY- - Y & $133.1^{\circ}$ \\
\hline 063 & $\begin{array}{l}\text { To Concur in Senate Amendment to Joint } \\
\text { Res. Promoting Peace and to Equalize } \\
\text { the Burdens and Minimize the Profit of } \\
\text { War }\end{array}$ & Yea & $S$ & YYYYYYN-NN- - YY & $109.6^{\circ}$ \\
\hline $066 \ddagger$ & $\begin{array}{l}\text { To Pass Bill Amending World War } \\
\text { Veterans Act of } 1924 \text { over Veto of the } \\
\text { President }\end{array}$ & Nay & $\mathrm{V}$ & NYYYYYN-YYYNYY & $104.7^{\circ}$ \\
\hline 069 & $\begin{array}{l}\text { To Recede and Concur in the Senate } \\
\text { Amendment to Deficiency Approp. Bill }\end{array}$ & Yea & $\mathrm{S}$ & YYYNYYN-YYN- - Y & $170.3^{\circ}$ \\
\hline 073 & $\begin{array}{l}\text { To Concur in Amendment to Res. that } \\
\text { Secretary of Agriculture Make } \\
\text { Advances and Loans for the Purchase } \\
\text { of Seeds, Fertilizer and Fuel Oil in } \\
\text { Drought and Storm Stricken Areas }\end{array}$ & Yea & $\mathrm{R}$ & YNNNNNYNNNNYYY & $91.7^{\circ}$ \\
\hline 074 & $\begin{array}{l}\text { To Pass Res. for the Relief of Farmers in } \\
\text { Drought or Storm Stricken Areas }\end{array}$ & Yea & $\mathrm{S}$ & YYYYYY-YYYYYYY & NA \\
\hline $083 \ddagger$ & $\begin{array}{l}\text { To Pass Act for Relief of Homer W. } \\
\text { Horine over Veto Of The President }\end{array}$ & Nay & $\mathrm{V}$ & -NNNNYNNNYNNNN & $118.5^{\circ}$ \\
\hline $087 \ddagger$ & $\begin{array}{l}\text { To Suspend Rules and Pass Bill to } \\
\text { Increase the Loan Basis of Adjusted } \\
\text { Service Certificates }\end{array}$ & Nay & $\mathrm{V}$ & YYYYYYYYYYYYYY & $90.3^{\circ}$ \\
\hline 089 & $\begin{array}{l}\text { To Agree Conf. Comm. Report on Res. } \\
\text { Providing for National Defense by } \\
\text { Creating a Corp. for Operation of } \\
\text { Government Properties at or near } \\
\text { Muscle Shoals, Alabama }\end{array}$ & Nay & $\mathrm{R}, \mathrm{V}$ & YYYYYYYYYYYYYY & $77.6^{\circ}$ \\
\hline 095 & $\begin{array}{l}\text { To Pass Bill To Amend } 1886 \text { Trade Act } \\
\text { Related to Oleomargarine }\end{array}$ & Yea & $S$ & YYYNYNYYNNYYYY & $150.2^{\circ}$ \\
\hline $096 \ddagger$ & $\begin{array}{l}\text { To Pass Bill to Increase the Loan Basis of } \\
\text { Adjusted Service Certificates over Veto } \\
\text { of the President }\end{array}$ & Nay & $\mathrm{V}$ & YYYYYYYYYY-YYY & $92.2^{\circ}$ \\
\hline
\end{tabular}




\section{(3) 71st House Roll Call Votes (continued)}

\begin{tabular}{|c|c|c|c|c|c|}
\hline No. & Description of Vote & $\mathrm{HH}$ & Basis & $\begin{array}{l}\text { Progressive Reps. } \\
\text { abcdefgjklmnop }\end{array}$ & $\begin{array}{l}\text { C.L. } \\
\text { Angle }\end{array}$ \\
\hline 099 & $\begin{array}{l}\text { To Suspend Rules and Pass Res. Restricting } \\
\text { Immigration }\end{array}$ & Yea & $\mathrm{R}$ & YYYNNYNYYYYYNY & $10.7^{\circ}$ \\
\hline 100 & $\begin{array}{l}\text { To Suspend Rules and Pass Bill Authorizing } \\
\text { Advances to the Reclamation Fund }\end{array}$ & Yea & $\mathrm{S}$ & - YNY - NYYYNNYYY & $59.4^{\circ}$ \\
\hline
\end{tabular}

(4) 72nd House Roll Call Votes

\begin{tabular}{|c|c|c|c|c|c|}
\hline No. & Description of Vote & $\mathrm{HH}$ & Basis & $\begin{array}{l}\text { Progressive Reps. } \\
\text { abcdefgijklmnop }\end{array}$ & $\begin{array}{l}\text { C.L. } \\
\text { Angle }\end{array}$ \\
\hline 004 & $\begin{array}{l}\text { To Pass Res. Authorizing Postponement of } \\
\text { Payments from Foreign Governments to } \\
\text { U.S. }\end{array}$ & Yea & $\mathrm{R}$ & NYNYNNYNNNNYYYY & $66.9^{\circ}$ \\
\hline 008 & $\begin{array}{l}\text { To Pass Bill Amending The Tariff Act Of } \\
1930\end{array}$ & Nay & $\mathrm{V}$ & Y-YYYYYYYYYYYYN & $102.0^{\circ}$ \\
\hline 011 & $\begin{array}{l}\text { To Instruct Conf. Comm. on Bill Providing } \\
\text { Emergency Financing Facilities for } \\
\text { Financial Institutions to Agree to } \\
\text { Amendment }\end{array}$ & Yea & $\mathrm{S}$ & YYYYYYYYYYYY - YN & $53.8^{\circ}$ \\
\hline 012 & $\begin{array}{l}\text { To Pass Bill Amending Section Three of the } \\
\text { Rivers and Harbors Act }\end{array}$ & Yea & $S$ & NNN-NYNYNYNYYNY & $90.0^{\circ}$ \\
\hline 014 & $\begin{array}{l}\text { To Suspend Rules and Pass Bill to Improve } \\
\text { the Facilities of Federal Reserve System }\end{array}$ & Yea & $\mathrm{R}, \mathrm{S}$ & YYYYNYNYYYYNYYY & $90.0^{\circ}$ \\
\hline 018 & $\begin{array}{l}\text { To Pass Bill Providing for Appointment of } \\
\text { Naval Academy Graduates }\end{array}$ & Yea & $S$ & NNNN-NNNN-NNNN- & $16.4^{\circ}$ \\
\hline 019 & $\begin{array}{l}\text { To Pass Joint Res. Authorizing the } \\
\text { Distribution of Government Owned Wheat } \\
\text { to the American National Red Cross and } \\
\text { Other Organizations for Relief of Distress }\end{array}$ & Yea & $\mathrm{S}$ & YYYYYYYYY-YYYYY & $N A$ \\
\hline 021 & $\begin{array}{l}\text { To Pass Bill Amending Judicial Code, } \\
\text { Defining and Limiting Jurisdiction of } \\
\text { Courts Sitting in Equity }\end{array}$ & Yea & $S$ & YYYYYYYYYYYYYYY & $104.7^{\circ}$ \\
\hline 028 & $\begin{array}{l}\text { To Pass Bill to Provide Revenue, Equalize } \\
\text { Taxation, and for Other Purposes, by } \\
\text { Eliminating Manufacturers Excise Tax }\end{array}$ & Yea & $\mathrm{R}, \mathrm{S}$ & YNYNNYYYYNNNYNN & $59.5^{\circ}$ \\
\hline $029 \dagger$ & $\begin{array}{l}\text { To Suspend Rules and Pass Bill Providing } \\
\text { for Withdrawal of Sovereignty of U.S. } \\
\text { over Philippine Islands }\end{array}$ & Nay & $\mathrm{V}$ & YYYYYYYYYYYYYYY & $72.0^{\circ}$ \\
\hline 032 & $\begin{array}{l}\text { To Pass Bill for Exemptions to Immigration } \\
\text { Quota }\end{array}$ & Yea & $\mathrm{S}$ & -YNYYYYYYNNY-YN & $17.8^{\circ}$ \\
\hline $038 \ddagger$ & $\begin{array}{l}\text { To Suspend Rules and Pass Bill to Amend } \\
\text { World War Veterans Act }\end{array}$ & Yea & $\mathrm{S}$ & YYYYYYYYYYY-YYY & $95.7^{\circ}$ \\
\hline 049 & $\begin{array}{l}\text { To Pass Bill Amending Tariff Act of } 1930 \\
\text { over Veto of the President }\end{array}$ & Nay & $\mathrm{V}$ & YYYYYYYYYYYYNYN & $103.2^{\circ}$ \\
\hline
\end{tabular}


(4) 72nd House Roll Call Votes (continued)

\begin{tabular}{|c|c|c|c|c|c|}
\hline No. & Description of Vote & $\mathrm{HH}$ & Basis & $\begin{array}{l}\text { Progressive Reps. } \\
\text { abcdefgijklmnop }\end{array}$ & $\begin{array}{l}\text { C.L. } \\
\text { Angle }\end{array}$ \\
\hline 060 & $\begin{array}{l}\text { To Pass a Bill Broadening the Powers of } \\
\text { the Reconstruction Finance Corp. and } \\
\text { Authorizing a Public Works Program }\end{array}$ & Nay & $\mathrm{R}$ & NNNYYYYYNY - YNYY & $116.8^{\circ}$ \\
\hline 069 & $\begin{array}{l}\text { To Recede and Concur in Senate } \\
\text { Amendment to Legislative Approp. Bill }\end{array}$ & Yea & $\mathrm{S}$ & YYY-YYNYYYYYYYN & $164.6^{\circ}$ \\
\hline 072 & $\begin{array}{l}\text { To Agree to the Report of the Conf. } \\
\text { Comm. on Bill Authorizing Interior } \\
\text { Secretary to Adjust Reimbursable } \\
\text { Debts of Indians and Tribes of Indians }\end{array}$ & Yea & $\mathrm{S}$ & NN- - YNYNNY - - YYY & $117.6^{\circ}$ \\
\hline 076 & $\begin{array}{l}\text { To Agree to Conf. Comm. Report on Bill } \\
\text { to Relieve Destitution, Broaden } \\
\text { Lending Powers of the Reconstruction } \\
\text { Finance Corp., and Create Employment } \\
\text { by Authorizing a Public Works } \\
\text { Program (H. R. 12445) }\end{array}$ & Nay & $\mathrm{R}, \mathrm{V}$ & YYYYYYYYYYYYYYY & $107.5^{\circ}$ \\
\hline 078 & $\begin{array}{l}\text { To Concur in a Senate Amendment to } \\
1933 \text { War Dept. Approp. Bill }\end{array}$ & Yea & $\mathrm{S}$ & YYY-YYYYYYYYNYN & $118.7^{\circ}$ \\
\hline 080 & $\begin{array}{l}\text { To Pass Bill to Relieve Destitution, } \\
\text { Broaden Lending Powers of the } \\
\text { Reconstruction Finance Corp., and } \\
\text { Create Employment by Providing for a } \\
\text { Public Works Program }\end{array}$ & Yea & $\mathrm{R}, \mathrm{S}$ & YYYYNYYYNYNYYYY & $30.8^{\circ}$ \\
\hline 083 & $\begin{array}{l}\text { To Agree to the Report of the Conf. } \\
\text { Comm. on Bill for Supp. Approp. for } \\
\text { Emergency Highway Construction to } \\
\text { Increase Employment }\end{array}$ & Yea & $\mathrm{R}$ & YYYYNYYYNYNYY-Y & $26.1^{\circ}$ \\
\hline 086 & $\begin{array}{l}\text { To Recede and Concur in Senate } \\
\text { Amendments to Bill to Create Federal } \\
\text { Home-Loan Banks }\end{array}$ & Yea & $\mathrm{S}$ & YYNNYNYNNYYY-YY & $19.9^{\circ}$ \\
\hline $097 \dagger$ & To Pass Philippine Independence Bill & Nay & $\mathrm{V}$ & YYYYYYYYYYYYYYY & $86.4^{\circ}$ \\
\hline 099 & $\begin{array}{l}\text { To Recede, Concur and Amend a Senate } \\
\text { Amendment to Bill Making Approp. To } \\
\text { Supply Urgent Deficiencies In Certain } \\
\text { Approp. }\end{array}$ & Nay & $\mathrm{V}$ & YYYYYYNYYYYYYYY & $89.9^{\circ}$ \\
\hline 105 & $\begin{array}{l}\text { To Pass Bill Making Approp. to Supply } \\
\text { Urgent Deficiencies in Certain Approp. } \\
\text { over Veto of the President }\end{array}$ & Nay & $\mathrm{V}$ & YYYYYYYYYYYY-N- & $96.5^{\circ}$ \\
\hline 120 & $\begin{array}{l}\text { To Suspend Rules and Pass Bill to } \\
\text { Provide for Creation of Morristown } \\
\text { National Historical Park }\end{array}$ & Yea & $\mathrm{S}$ & - -NYNNYNYYNNYNY & $90.0^{\circ}$ \\
\hline 122 & $\begin{array}{l}\text { To Pass Bill Providing for Purchase and } \\
\text { Sale of Cotton under Supervision of the } \\
\text { Secretary of Agriculture }\end{array}$ & Nay & $\mathrm{PV}$ & NNYNYYNYYYYNNNN & $115.0^{\circ}$ \\
\hline 123 & $\begin{array}{l}\text { To Suspend Rules and Pass Bill to Provide } \\
\text { for Selection of Certain Public Lands in } \\
\text { California for a State Park System }\end{array}$ & Yea & $\mathrm{S}$ & Y-Y-NNYNYYYY-YY & $108.9^{\circ}$ \\
\hline
\end{tabular}


B. C. Edwards

Appendix B. Hoover's Ideal Point in Relation to 71st and 72nd Congresses (Using Optimal Classification) (color figure available online)

(a) 71st House

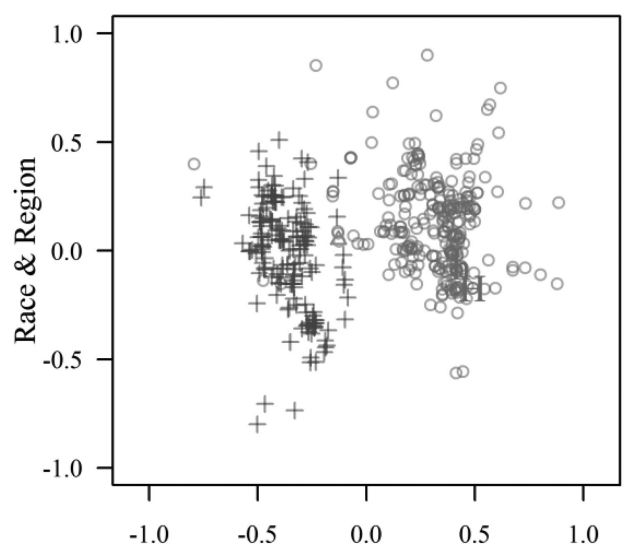

(c) 72nd House

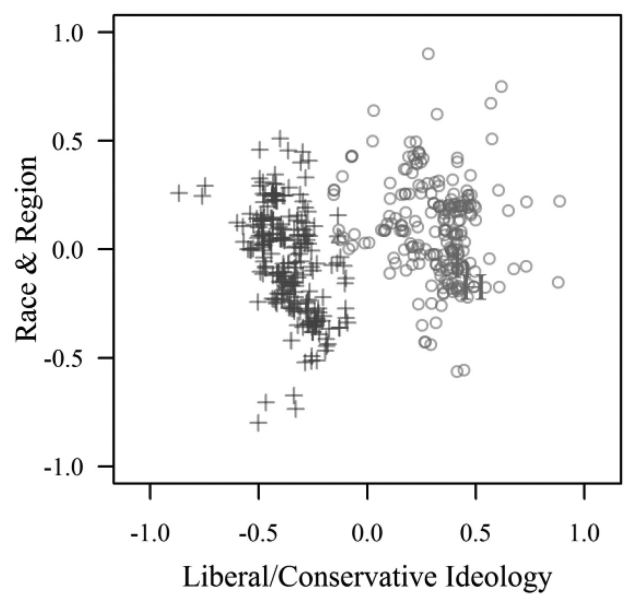

(b) 71st Senate

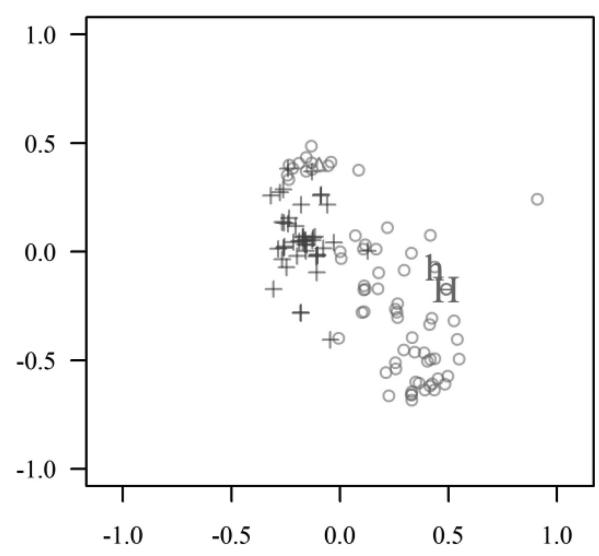

(d) 72nd Senate

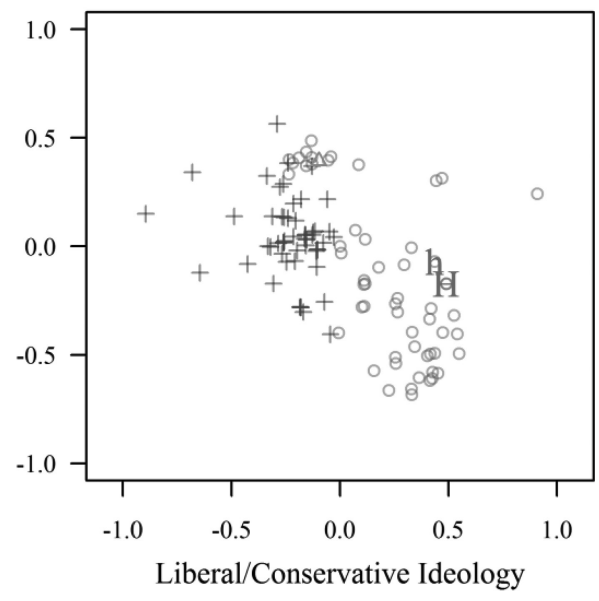

\begin{tabular}{clll}
\hline & Republicans & H Hoover \\
+ & Democrats & h & Hoover (requests only) \\
$\Delta$ & Farm-Labor & & \\
\hline
\end{tabular}


Appendix C. Hoover's Ideal Point in Relation to 71st and 72nd Congresses (Using IDEAL) (color figure available online)

(a) 71st House

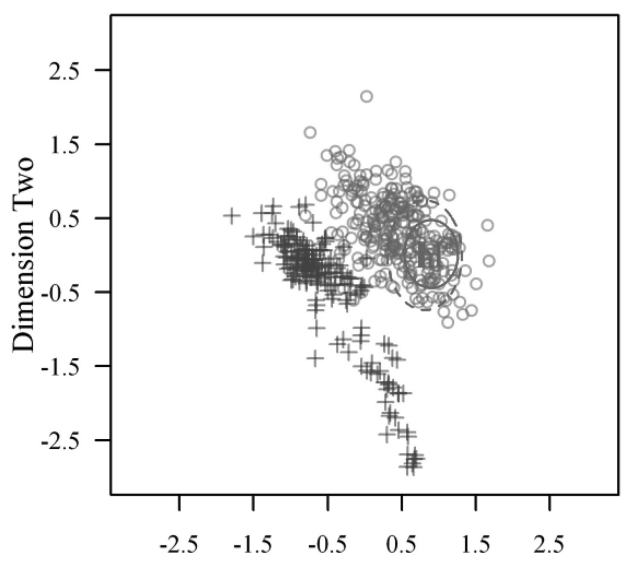

(c) 72nd House

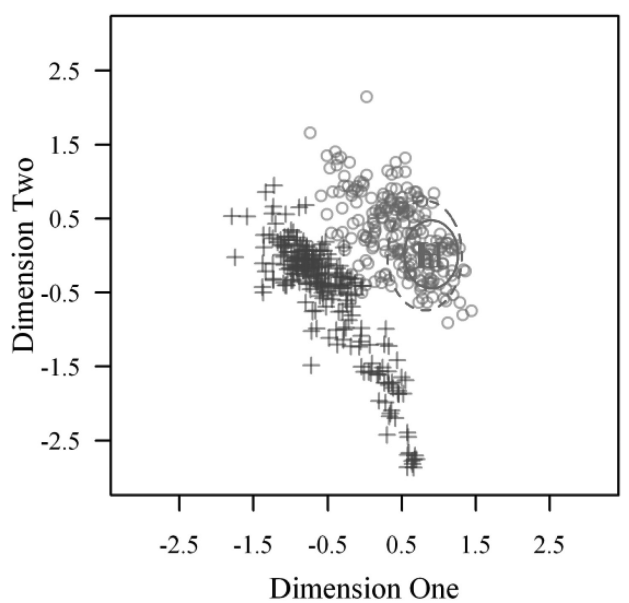

(b) 71st Senate

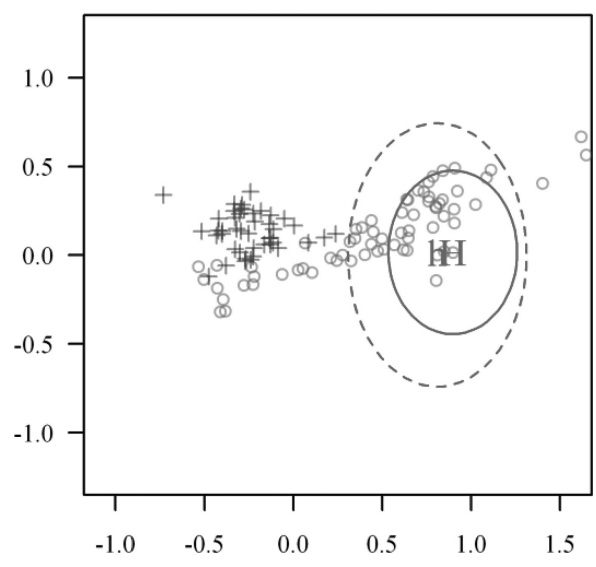

(d) 72nd Senate

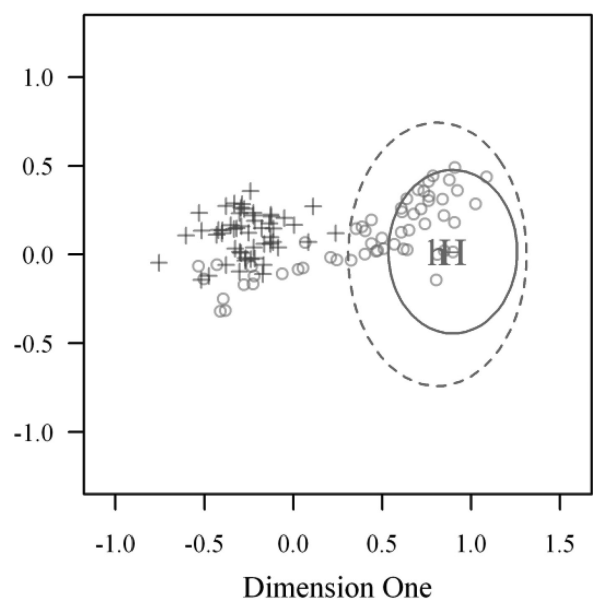

\begin{tabular}{|clcll|}
\hline$\circ$ & Republicans & $\mathrm{H}$ & Hoover & - \\
+ & Democrats & $\mathrm{h}$ & Hoover (requests only) & $---95 \%$ Confidence Interval \\
& & &
\end{tabular}

